\title{
СМЕРТНОСТЬ ОТ БОЛЕЗНЕЙ СИСТЕМЫ КРОВООБРАЩЕНИЯ И ПРОДОЛЖИТЕЛЬНОСТЬ ЖИЗНИ В РОССИИ *
}

\author{
АНАТОЛИЙ ВИШНЕВСКИЙ ${ }^{1, * *}$, ЕВГЕНИЙ АНДРЕЕВ², СЕРГЕЙ ТИМОНИН ${ }^{1}$
}

\begin{abstract}
Высокая преждевременная смертность от болезней системы кровообращения и ее долговременная неблагоприятная динамика - одна из главных причин отставания России от развитых стран по продолжительности жизни, особенно женской части ее населения. Несмотря на снижение смертности после 2003 г., коэффициенты смертности от БСК в ряде ключевых возрастных групп (30-74 года у мужчин и 30-49 лет у женщии) остаются выще, чем они были в 1970 г.

Анализ долговременных изменений продолжительности жизни в России свидетельствует об отрицательном итоговом вкладе изменений в смертности от БСК у мужчин (-1,0 года за 19722010 г2.) и незначительном положительном - у женщин (+0,7 года за 1972-2010 г2.).

Структура смертности внутри класса сердечно-сосудистых заболеваний в России значительно отличается от структуры, характерной для стран с наиболее низким уровнем смертности от БСК. Больше половины смертей приходится на ишемическую болезнь сердча, и эта доля в отличие от западных стран имеет тенденцию к росту. На втором месте - смерти от иереброваскулярных заболеваний, доля которых хоть и снижается, но остается значительно выше, нежели в странах Запада. На долю смертей от всех остальных сердечно-сосудистых заболеваний в западных странах приходится около 50\% смертей, в то время как в России - около 15\%, но в России они характеризуются весьма низким возрастом смерти.
\end{abstract}

Рассматриваются региональные особенности смертности от болезней системы кровообращения 8 России и обсуждаются вопросы качества статистики причин смерти и изменения практики кодирования причин смерти в субъектах Российской Федерации.

Ключевые слова: смертность, продолжительность жизни, болезни системы кровообращчения, ишемическая болезнь сердия, цереброваскулярные болезни, возрастная модель смертности, средний возраст смерти, избыточные смерти.

Демографическое развитие Российской Федерации определяется взаимодействием трех главных демографических процессов: рождаемости, смертности и миграции. Каждый из этих процессов в современной России протекает в режиме, далеком от оптимального, порождает множество проблем, вызывающих обеспокоенность общества и рассматриваемых как вызовы, на которые необходимо найти ответы.

Один из таких вызовов, возможно наиболее острый, связан с очень высоким уровнем смертности и, соответственно, низкой продолжительностью жизни россиян.

\footnotetext{
${ }^{1}$ НАЦИОНАЛЬНЫЙ ИССЛЕДОВАТЕЛЬСКИЙ УНИВЕРСИТЕТ «ВЫСШАЯ ШКОЛА ЭКОНОМИКИ» (РОССИЯ); ${ }^{2}$ РОССИЙСКАЯ ЭКОНОМИЧЕСКАЯ ШКОЛА (РОССИЯ).

* В ДАННОЙ НАУЧНОЙ РАБОТЕ ИСПОЛЬЗОВАНЫ РЕЗУЛЬТАТЫ ПРОЕКТА «ТЕНДЕНЦИИ ДЕМОГРАФИЧЕСКОГО РАЗВИТИЯ РОССИИ В 2005-2015 ГГ. В КОНТЕКСТЕ ДОЛГОВРЕМЕННЫХ ДЕМОГРАФИЧЕСКИХ ТРЕНДОВ», ВЫПОЛНЕННОГО В РАМКАХ ПРОГРАММЫ ФУНДАМЕНТАЛЬНЫХ ИССЛЕДОВАНИЙ НИУ ВШЭ В 2016 ГОДУ. УЧАСТИЕ ТИМОНИН С.А. ПОДДЕРЖАНО РФФИ (НАУЧНЫЙ ПРОЕКТ № 16-36-00374).
}

** E-mail: avishnevsky@hse.ru

СТАТЬЯ ПОСТУПИЛА В РЕДАКЦИЮ В НОЯБРЕ 2015 Г. 


\section{ОТСТАВАНИЕ РОССИИ ПО ПРОДОЛЖИТЕЛЬНОСТИ ЖИЗНИ}

К середине 1960-х годов в большинстве развитых индустриальных стран удалось установить контроль над главным источником высокой смертности в прошлом инфекционными заболеваниями. Благодаря этому ожидаемая продолжительность жизни между началом XX века и 1960 г. выросла на 20 и более лет, причем Россия, имевшая очень низкий исходный уровень, принадлежала к числу стран, достигших на этом этапе наибольшего выигрыша: продолжительность жизни мужчин в России выросла на 34 года, женщин - на 40 лет, она значительно сократила свое отставание от многих европейских стран и даже обогнала некоторые из них (рисунок 1).

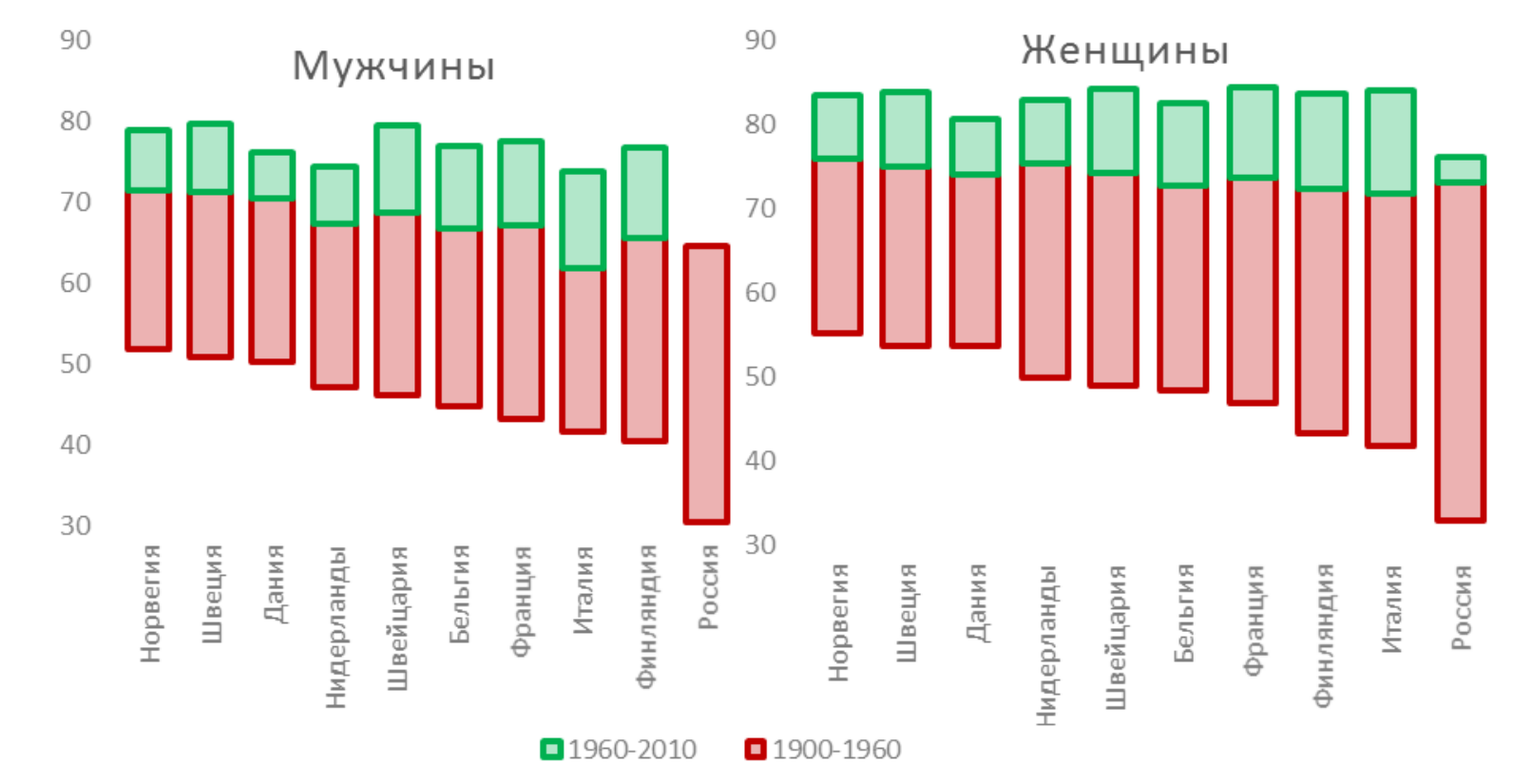

\section{Рисунок 1. Ожидаемая продолжительность жизни в 1900 г. и ее прирост в некоторых странах на этапах первой и второй эпидемиологических революций, лет (нижний край столбиков соответствует 1900 году)}

Источник: Расчеты авторов по данным [РосБРиС 2015; HLD 2015; HMD 2015].

Это была настоящая революция, в результате которой ожидаемая продолжительность жизни во многих развитых странах увеличилась в среднем до 70 лет, ее дальнейший рост существенно замедлился, а главными причинами смерти стали «дегенеративные заболевания и болезни, связанные с деятельностью человека» [Omran 1971: 510]. Оценивая сложившуюся ситуацию, эксперты пришли к выводу, что возможности прежней стратегии борьбы за повышение продолжительности жизни, ориентированной прежде всего на профилактику и лечение инфекционных заболеваний, исчерпываются, и эта стратегия нуждается в переосмыслении. Как писал американский гигиенист Милтон Террис, необходимо было совершить «вторую эпидемиологическую революцию» [Terris 1976: 1159].

Мир действительно вступил в новую эру - эпоху борьбы с неинфекционными причинами смерти (хроническими заболеваниями, а также несчастными случаями и травмами). Примерно с конца 1960-х - начала 1970-х годов в большинстве развитых стран шел процесс активной трансформации эпидемиологической модели смертности, 
сложившейся к этому времени в результате достигнутых на предыдущем этапе успехов в борьбе с инфекционными заболеваниями. И именно рубеж 1960-х-1970-х годов стал точкой, когда пути снижения смертности в индустриальных странах начали расходиться, переход к новой модели смертности шел не везде.

Он был успешным в странах Западной Европы, Северной Америки, Японии и некоторых других странах, где сохранялась устойчивая тенденция к увеличению продолжительности жизни (прибавка составляла примерно 2,5 года в десятилетие). В странах же Центральной и Восточной Европы никаких улучшений не происходило. В СССР это неблагополучие долго замалчивалось, и только в конце 1980-х годов появилась возможность сказать во всеуслышание, что в стране, «начиная, примерно, с середины шестидесятых годов, наступил длительный период «топтания на месте». Сохранялась, а в некоторых случаях и росла, и без того относительно высокая смертность, особенно мужчин в рабочих возрастах, увеличивалось отставание СССР по показателям смертности и средней продолжительности предстоящей жизни от большинства экономически развитых стран мира» [Вишневский 1986: 71-72].

Все это относилось и к России. Насколько выигрышными для нее были изменения на этапе первой эпидемиологической революции, настолько же проигрышными оказались они на более позднем этапе, когда в мире развернулась вторая эпидемиологическая революция. За 50 лет (между 1960 и 2010 гг.) продолжительность жизни женщин выросла незначительно - намного меньше, чем в большинстве развитых стран, а у мужчин она даже несколько сократилась. Отставание России снова увеличилось (рисунок 1).

Негативные тенденции в Центральной Европе были сломлены в конце 1980-х годов, в Прибалтике - в середине 1990-х. В России изменения, происходившие с конца 1980-х годов, когда были достигнуты самые высокие показатели продолжительности жизни, имели колебательный характер. Вначале показатели резко упали, достигнув дна в 1994 г., после чего последовало их восстановление. Падение заняло 4-6 лет, а на восстановление уровня конца 1980-х годов, временно прервавшееся в 1998 г., потребовалось в целом 15 лет у женщин и 19 лет у мужчин. При этом отставание от большинства развитых стран существенно выросло. Если взять для сравнения 15 западноевропейских стран ${ }^{1}$, входивших в Европейский союз до его расширения в 2004 г. (ЕС-15), то в 1988 г. продолжительность жизни мужчин в России была ниже, чем в этих странах, на 8 лет, женщин - на 5 лет. Через 25 лет, в 2013 г., после ряда колебаний этот разрыв составлял 13,9 года у мужчин и 7,9 года у женщин. Если же сравнивать с отдельными, наиболее успешными странами (Франция, Италия, Испания, Япония), то разрыв будет еще большим. Нарастающее отставание России от обогнавших ее по продолжительности жизни стран, в том числе и из бывшего «социалистического лагеря», хорошо видно на рисунке 2.

Наблюдаемое отставание в решающей степени предопределяют две особенности современной российской модели смертности: очень высокая смертность от болезней системы кровообращения в средних возрастах и очень высокая смертность от внешних

\footnotetext{
${ }^{1}$ Австрия, Бельгия, Великобритания, Германия, Греция, Дания, Италия, Ирландия, Испания, Люксембург,
} Нидерланды, Португалия, Финляндия, Франция, Швеция. 
причин в молодых и средних возрастах [Вишневский, Школьников 1997: 24]. В настоящей статье более подробно рассматривается одна из этих двух особенностей - высокая смертность россиян от болезней системы кровообращения.

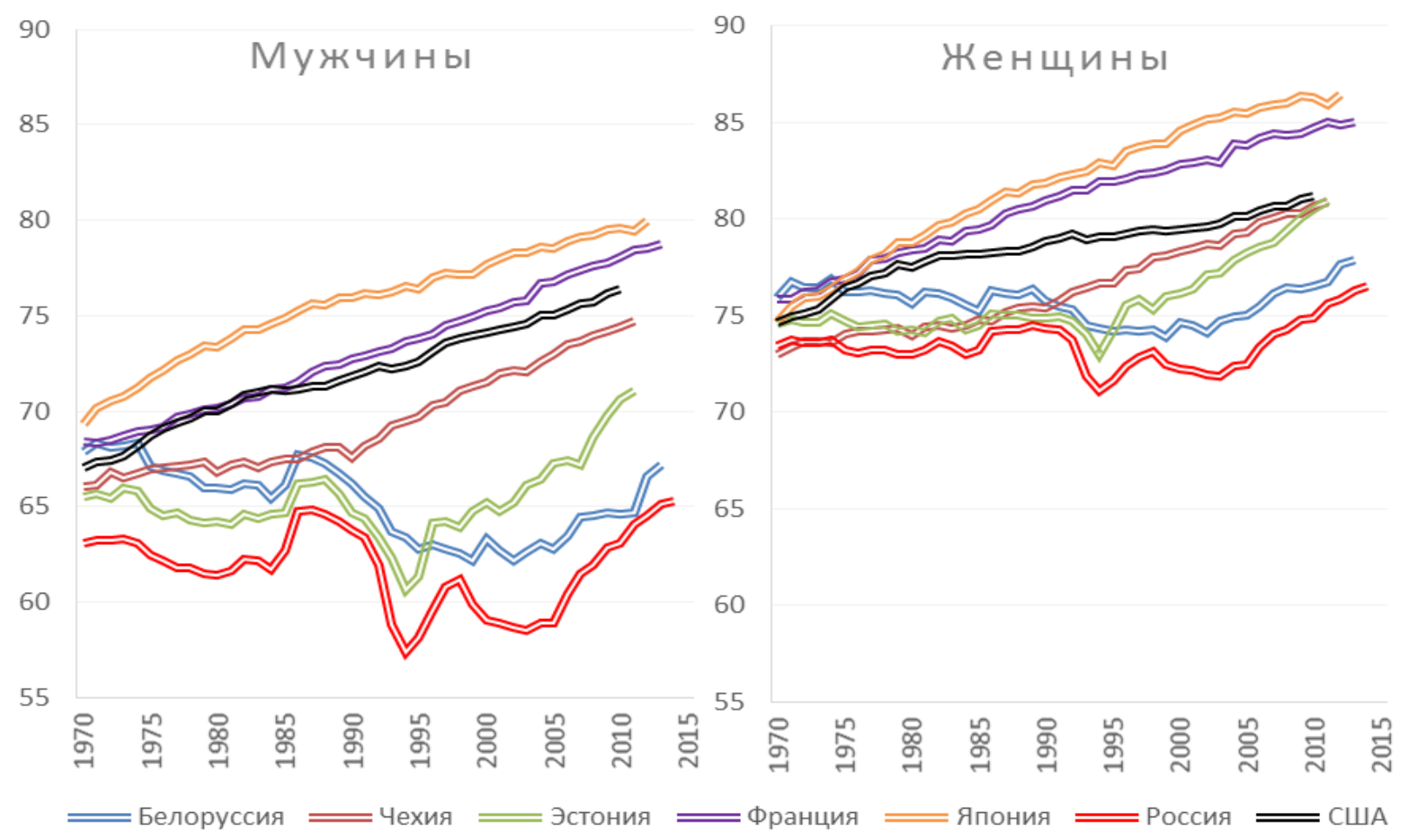

Рисунок 2. Ожидаемая продолжительность жизни при рождении в России и некоторых странах мира, лет

Источник: Расчеты авторов по данным [РосБРиС 2015; НMD 2015].

\section{НЕБЛАГОПРИЯТНАЯ ДИНАМИКА СМЕРТНОСТИ ОТ БОЛЕЗНЕЙ СИСТЕМЫ КРОВООБРАЩЕНИЯ В РОССИИ}

В исторической ретроспективе высокая смертность от болезней системы кровообращения - не беда, а благо. Во второй половине XIX - первой половине XX века стремительный рост смертности от причин преимущественно эндогенной этиологии, прежде всего болезней системы кровообращения и новообразований, был в высшей степени прогрессивным процессом, потому что рост вероятности умереть от этих причин одновременно означал снижение вероятности умереть от экзогенных причин, в первую очередь, от инфекционных заболеваний, что было тождественно вытеснению смертей в детских и молодых возрастах смертями людей в пожилом и преклонном возрасте и быстрому росту ожидаемой продолжительности жизни.

В результате произошедших изменений смертность от болезней системы кровообращения стала важнейшей, доминирующей частью общей смертности во всех развитых странах, а для России это было даже более характерно, чем для западных стран. На протяжении последних десятилетий минувшего века вероятность умереть от причин этого класса несколько менялась, но ее определяющая роль сохранялась: около половины 
мужчин и 65-70\% женщин умирали от этой причины, что уже тогда заметно отличало российскую модель смертности от западной, где вероятность умереть от болезней системы кровообращения была заметно ниже [Вишневский, Школьников 1997: 27].

Увеличение вклада болезней системы кровообращения в общую смертность (для своего времени явление позитивное) сочеталось с повышением среднего возраста смерти от этой причины, в том числе и в СССР, где «на протяжении длительного периода смертность от болезней системы кровообращения... снижалась в более молодых возрастных группах - рост ее наблюдался только в возрастах старше 50 лет, да и то он мог быть связан здесь с улучшением диагностики» [Воспроизводство населения 1983: 111]. Однако уже во второй половине 1960-х годов «обнаружилась новая тенденция - к повышению смертности в средних возрастах, в которых она прежде снижалась» [Воспроизводство населения 1983: 112]. В результате «средний возраст умерших от сердечно-сосудистых заболеваний с 1966-1967 по 1971-1972 гг. снизился у женщин примерно на один год, а у мужчин даже на два» [Бирюков 1979: 66].

На «тревожные тенденции» смертности от сердечно-сосудистых заболеваний в России указывалось и в более поздних работах. Например, сравнение России с Францией, выполненное в середине 1990-х годов, показало, что в России «смертность от сердечнососудистых заболеваний существенно выше, чем во Франции, и, что особенно важно, увеличивается на протяжении последних 30 лет, тогда как во Франции происходит ее непрерывное сокращение... Это принципиальное различие свидетельствует о том, что Россия, в отличие от западных стран, не встала еще на путь эффективной борьбы с сердечно-сосудистыми заболеваниями, что позволило бы ей вступить в новую фазу эпидемиологического перехода» [Милле и др. 1996: 117-118].

Судя по всему, эта новая фаза не наступила в России и до сих пор, хотя, истины ради, надо сказать, что дело не только в сердечно-сосудистых заболеваниях. К началу 1970-х годов в России, как и во всех в развитых странах, инфекционные заболевания утратили свою недавнюю роль главной угрозы здоровью и жизни человека, и на первый план вышли неинфекционные причины заболеваемости, инвалидности и смертности, прежде всего три их главных класса: сердечно-сосудистые заболевания, новообразования и так называемые внешние причины смерти, вызванные не болезнями, а преднамеренными или случайными внешними воздействиями.

В 1970 г. совокупная доля этих трех групп причин в стандартизованном коэффициенте смертности от всех причин в странах Западной Европы была близка к 70\% и в последующие годы даже увеличивалась, а в России уже тогда достигала 80\%. Соответственно задачи борьбы со смертностью сводились и все еще сводятся прежде всего к снижению смертности от трех указанных групп причин [Вишневский 2014]. 
EC-15, мужчины
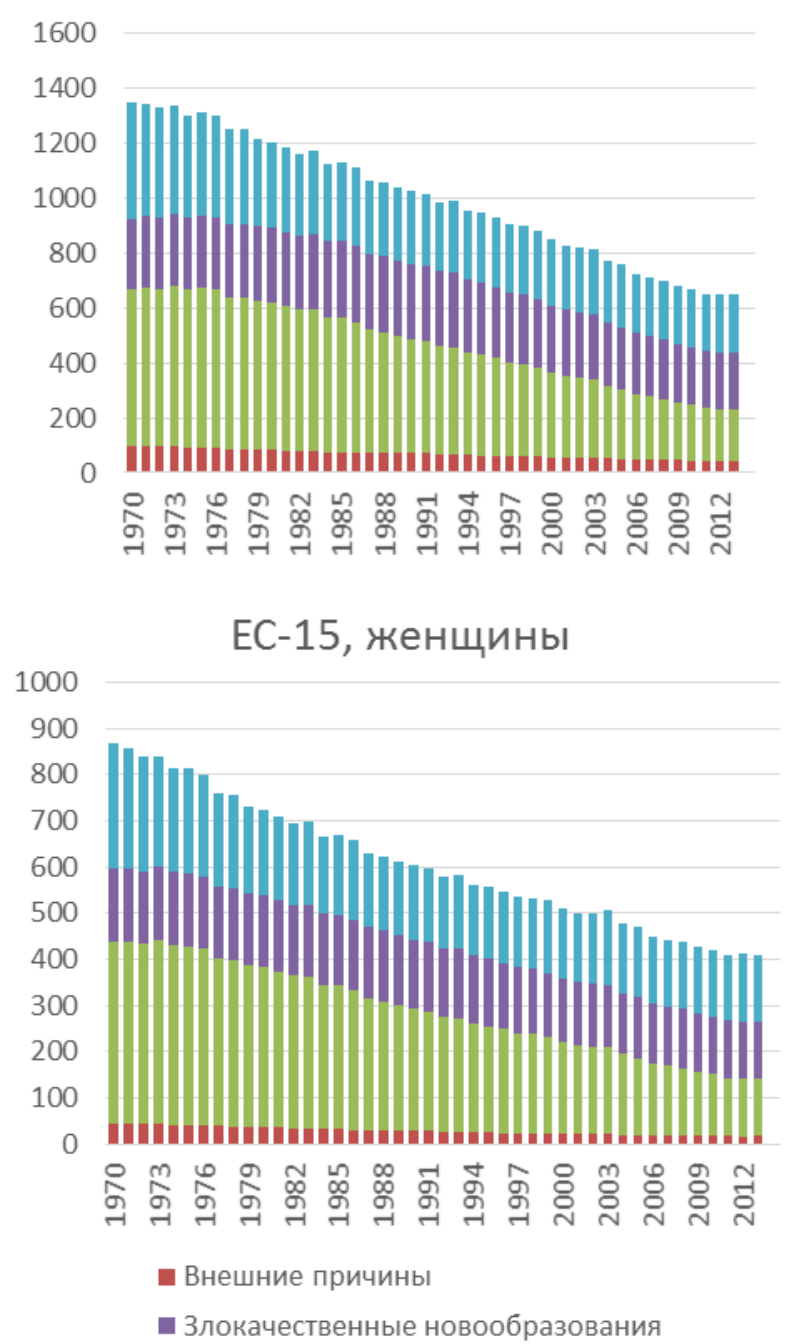

Россия, мужчины
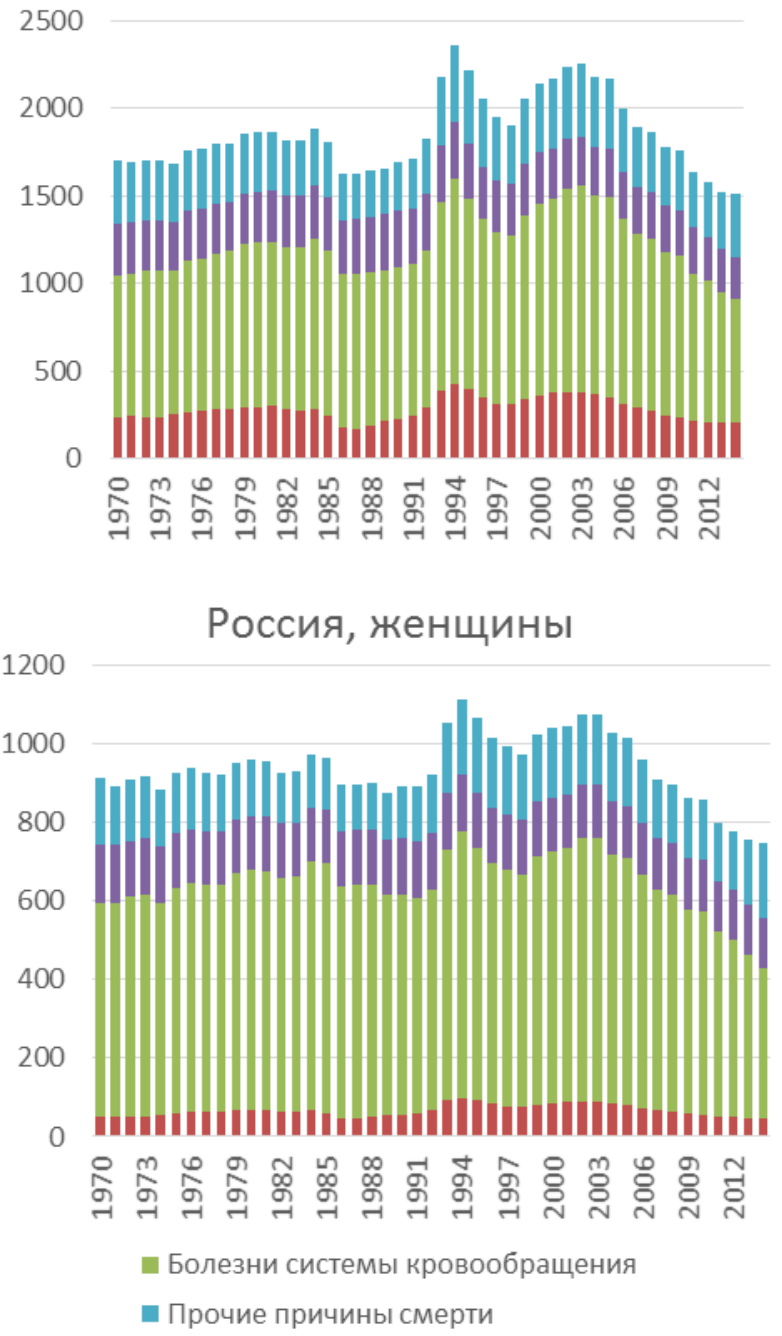

Рисунок 3. Стандартизованный коэффициент смертности от болезней системы кровообращения, злокачественных новообразований, внешних причин и прочих причин смерти ЕС-15 и России, на 100000

Источник: Расчеты авторов по данным [РосБРиС 2015; WНО МD 2015]

Если судить по динамике стандартизованного коэффициента смертности после 1970 г., то эти задачи в западноевропейских странах решались весьма успешно (рисунок 3 , левая панель). При этом график однозначно свидетельствует, что всю картину изменений на протяжении последних десятилетий определяло снижение стандартизованного коэффициента смертности от болезней системы кровообращения, именно оно привело к общему снижению стандартизованного коэффициента смертности в этих странах. Стандартизованный коэффициент смертности от двух других главных классов неинфекционных причин изменился незначительно (хотя в случае внешних причин его снижение все же заметно). Неслучайно поэтому в современной демографической литературе происходившие в последние полвека изменения в смертности получили название «кардиоваскулярной революции» [Meslé, Vallin 2006: 250]. 
В России события развивались по-иному. Как видно из того же рисунка 3 (правая панель) и из таблицы 1 , здесь о серьезном снижении смертности от болезней системы кровообращения говорить пока не приходится, с 1970 г. она почти не изменилась. Едва ли можно говорить и о серьезном изменении совокупного стандартизованного коэффициента смертности от трех классов причин - за последние полвека он претерпевал, в основном, колебательные изменения, лишь во второй половине «нулевых» годов обнаружив более или менее выраженную тенденцию к падению ниже достигавшихся ранее уровней.

Таблица 1. Стандартизованный коэффициент смертности от некоторых классов причин смерти в России, 1970-2014, на 100000

\begin{tabular}{|c|c|c|c|c|c|c|}
\hline & 1970 & 1980 & 1990 & 2000 & 2010 & 2014 \\
\hline & \multicolumn{6}{|c|}{ Мужчины } \\
\hline $\begin{array}{l}\text { Все причины } \\
\text { в том числе: }\end{array}$ & 1704,5 & 1868,2 & 1695,4 & 2143,6 & 1756,5 & 1513,2 \\
\hline • болезни системы кровообращения & 809,0 & 946,2 & 868,0 & 1091,8 & 920,5 & 702,1 \\
\hline - злокачественные новообразования & 287,2 & 284,5 & 318,6 & 294,4 & 262,8 & 241,0 \\
\hline • внешние причины & 238,8 & 292,1 & 228,7 & 360,5 & 237,3 & 204,4 \\
\hline Итого 3 класса причин & 1335,0 & 1522,8 & 1415,3 & 1746,7 & 1420,6 & 1147,5 \\
\hline \multirow[t]{2}{*}{ - остальные причины } & 369,5 & 345,4 & 280,1 & 396,9 & 335,9 & 365,8 \\
\hline & \multicolumn{6}{|c|}{ Женщины } \\
\hline $\begin{array}{l}\text { Все причины } \\
\text { в том числе: }\end{array}$ & 911,7 & 959,1 & 893,3 & 1039,2 & 858,9 & 747,2 \\
\hline - болезни системы кровообращения & 544,9 & 610,4 & 561,9 & 641,4 & 517,6 & 382,4 \\
\hline • злокачественные новообразования & 146,2 & 135,8 & 142,8 & 139,8 & 131,8 & 123,1 \\
\hline - внешние причины & 51,1 & 68,0 & 55,8 & 83,3 & 56,9 & 47,8 \\
\hline Итого 3 класса причин & 742,2 & 814,2 & 760,5 & 864,5 & 706,3 & 553,4 \\
\hline • остальные причины & 169,5 & 144,9 & 132,8 & 174,7 & 152,6 & 193,8 \\
\hline
\end{tabular}

Источник: Расчеты авторов по данным [РосБРиС 2015].

\section{ВЫСОКАЯ СМЕРТНОСТЬ ОТ СЕРДЕЧНО-СОСУДИСТЫХ ЗАБОЛЕВАНИЙ - ГЛАВНАЯ ПРИЧИНА НИЗКОЙ ПРОДОЛЖИТЕЛЬНОСТИ ЖИЗНИ В РОССИИ}

Высокая смертность от сердечно-сосудистых заболеваний - главный виновник российского отставания от других стран по продолжительности жизни. Она на 45-55\% обусловливает это отставание у мужчин и еще больше - у женщин (таблица 2).

С начала 1970-х годов уровень смертности в России пережил несколько периодов подъема и спада, и каждый раз это было тесно связано с подъемами и спадами смертности от болезней системы кровообращения (рисунки 4 и 5).

Так как периоды роста и снижения смертности от болезней системы кровообращения чередовались, можно найти периоды, когда борьба с этой причиной смерти может рассматриваться как успешная. В частности, такую интерпретацию можно предложить для периода с 2004 г., когда, как следует из рисунков 4 и 5, вклад снижения смертности от сердечно-сосудистых заболеваний в рост продолжительности жизни был большим, чем во многих других странах [Grigoriev et al. 2014]. Однако все же нельзя не учитывать, что в основном этот вклад компенсировал потери, понесенные в предыдущие периоды. В долговременном плане (за период с 1972 г., который отражен на рисунках 4 и 5) итоговый вклад изменений в смертности от болезней системы кровообращения в 
изменения продолжительности жизни у женщин был хотя и положительным, но очень небольшим по сравнению с другими странами, а у мужчин он и вовсе был отрицательным.

Таблица 2. Вклад различий в смертности от болезней системы кровообращения (БСК) в общее отставание России по ожидаемой продолжительности жизни от некоторых стран

\begin{tabular}{|c|c|c|c|c|c|c|}
\hline \multirow{3}{*}{ Страна, год } & \multicolumn{3}{|c|}{ Мужчины } & \multicolumn{3}{|c|}{ Женщины } \\
\hline & \multirow{2}{*}{$\begin{array}{c}\text { различия в } \\
\text { ожидаемой } \\
\text { продолжительности } \\
\text { жизни, лет }\end{array}$} & \multicolumn{2}{|c|}{$\begin{array}{c}\text { в том числе за счет } \\
\text { более высокой } \\
\text { смертности от БСК }\end{array}$} & \multirow{2}{*}{$\begin{array}{c}\text { различия в } \\
\text { ожидаемой } \\
\text { продолжительности } \\
\text { жизни, лет }\end{array}$} & \multicolumn{2}{|c|}{$\begin{array}{l}\text { в том числе за счет } \\
\text { более высокой } \\
\text { смертности от БСК }\end{array}$} \\
\hline & & лет & $\%$ & & лет & $\%$ \\
\hline Япония, 2013 & 15,4 & 7,9 & 51,1 & 11,0 & 7,9 & 71,3 \\
\hline Франция, 2011 & 13,5 & 7,6 & 55,8 & 9,2 & 7,3 & 78,8 \\
\hline Германия, 2012 & 13,4 & 6,4 & 47,6 & 7,0 & 4,8 & 69,0 \\
\hline США, 2010 & 11,4 & 6,1 & 53,4 & 5,0 & 5,0 & 98,1 \\
\hline Эстония, 2012 & 10,1 & 4,3 & 42,7 & 4,9 & 2,9 & 60,3 \\
\hline Чехия, 2013 & 6,2 & 2,8 & 44,3 & 5,1 & 2,7 & 53,7 \\
\hline
\end{tabular}

Примечание: Данные по России, используемые для сравнения, - за 2013 г. (ожидаемая продолжительность жизни составила 65,1 и 76,4 лет для мужчин и женщин соответственно).

Источник: Расчеты авторов по данным [РосБРиС 2015; WНО МD 2015].

Все причины смерти

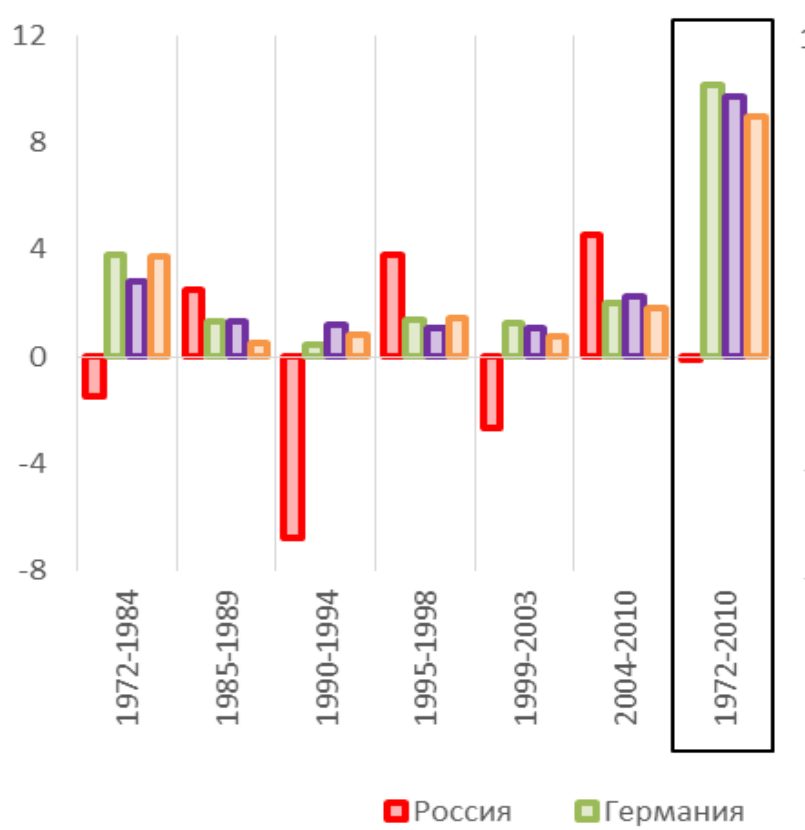

Болезни системы кровообращения

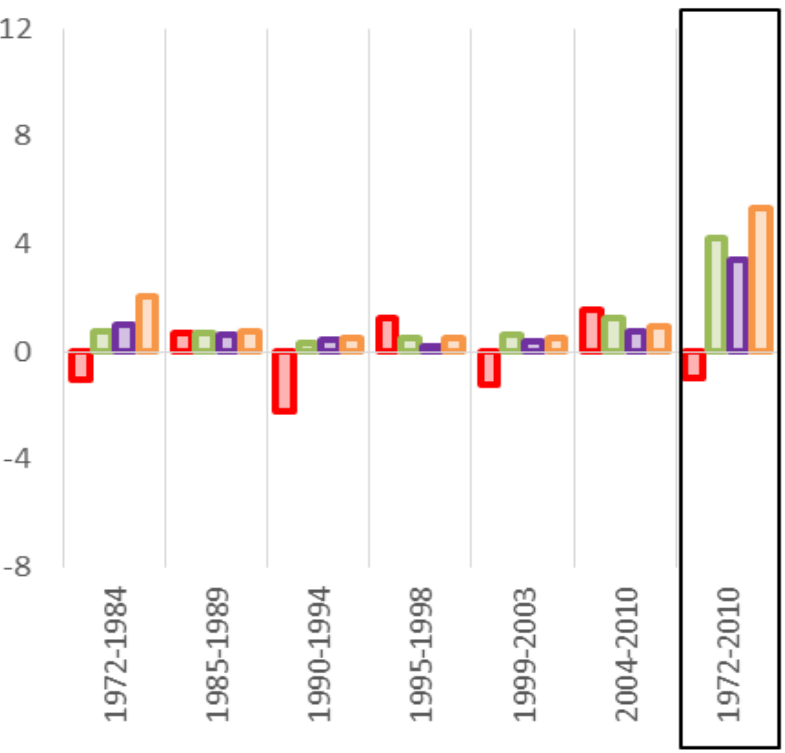

口Франция 口США

Рисунок 4. Изменения ожидаемой продолжительности жизни при рождении в результате роста или снижения смертности от всех причин и от болезней системы кровообращения в России, Германии, Франции и США, мужчины, лет

Источник: Расчеты авторов по данным [РосБРиС 2015; WНО MD 2015]. 
Bсе причины смерти

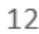

12

$-8$

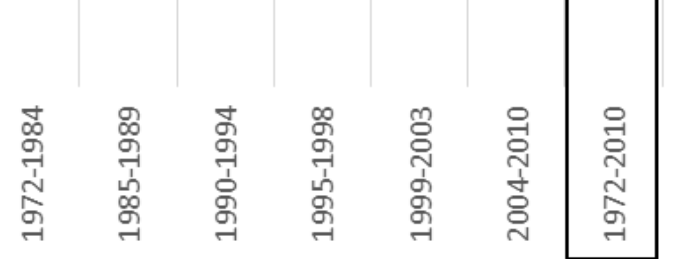

Болезни системы кровообращения

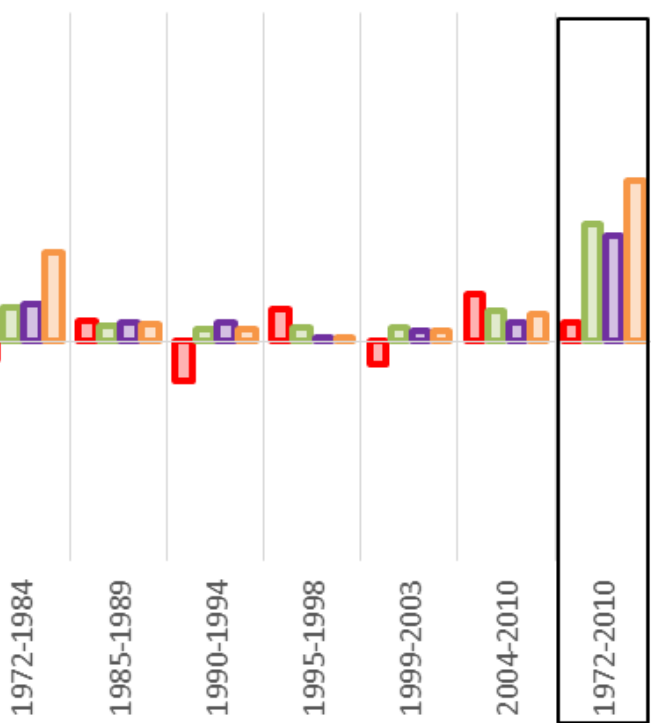

口Россия

口Германия

Франция

口США

Рисунок 5. Изменения ожидаемой продолжительности жизни при рождении в результате роста или снижения смертности от всех причин и от болезней системы кровообращения в России, Германии, Франции и США, женщины, лет

Источник: Расчеты авторов по данным [РосБРиС 2015; WHО МD 2015].

\section{СТРУКТУРА СЕРДЕЧНО-СОСУДИСТОЙ СМЕРТНОСТИ В РОССИИ}

Укрупненно структурируя весь класс болезней системы кровообращения, можно выделить три главные группы этих болезней: ишемическая болезнь сердца (коды по МКБ-10 [ВОЗ 1995] I20-I25), цереброваскулярные болезни (I60-I69) и все остальные причины этого класса (другие болезни сердца - коды I00-I19, I26-I59 - и прочие сердечно-сосудистые заболевания - коды 170-199). Сопоставление структуры смертности от этих трех групп причин в России и в странах с более низкой и снижающейся смертностью от болезней системы кровообращения говорит о том, что и здесь Россия идет своим - и не самым лучшим - путем.

В 1970-е годы предпринимались попытки связать неблагоприятные тенденции в смертности от болезней системы кровообращения в России с различной ролью экзогенных и эндогенных причин и условий возникновения разных групп сердечно-сосудистых заболеваний. Предполагалось, что «такие, скажем, заболевания, как активный ревматизм и хроническая ревматическая болезнь сердца, можно рассматривать в основном как заболевания экзогенной этиологии, тогда как ишемическая болезнь сердца, сосудистые поражения мозга - заболевания по преимуществу эндогенные» [Бирюков 1979: 69]. Логика этого противопоставления заключалась в том, что большая роль экзогенного компонента в детерминации тех или иных сердечно-сосудистых заболеваний делает их менее зависимыми от возраста и в то же время более чувствительными к тем методам борьбы с болезнями и смертью, которые принесли успех на более ранних стадиях 
эпидемиологического перехода. Установление контроля над мало зависящими от возраста экзогенными факторами сердечно-сосудистой заболеваемости в каком-то смысле могло бы рассматриваться как развитие этого успеха, повышающее шансы на снижение смертности именно от тех болезней системы кровообращения, в этиологии которых роль этого фактора была наиболее высока.

Учитывая, что основной вклад в сердечно-сосудистую смертность вносят ишемическая болезнь сердца и сосудистые поражения мозга, Бирюков полагал, что было бы интересно связать различия в динамике смертности от этих двух групп заболеваний с разным вкладом экзогенных и эндогенных компонентов в их этиологию. Однако он не смог этого сделать и вынужден был признать, что «пока сделать такой анализ убедительным не удается» [Бирюков 1979: 74]. Все же отметив, что и ишемическая болезнь сердца, и сосудистые поражения мозга имеют в своей основе либо атеросклероз, либо гипертонию, причем в первом случае ведущее место принадлежит атеросклерозу, а во втором гипертонической болезни, В. Бирюков обращает внимание на то, что «борьба с гипертонической болезнью ведется более успешно», и делает осторожное предположение, что «смертность от гипертонической болезни менее тесно связана с возрастом, а значит и в меньшей степени служит неизбежным спутником процесса старения» [Бирюков 1979: 75], иными словами, что она меньше зависит от средовых и поведенческих факторов.

По-видимому, это предположение, как и вся логика рассуждения Бирюкова, не были лишены оснований. Уже в 90-е годы авторы упомянутого сравнительного исследования смертности в России и Франции пришли к выводу, что в России «благоприятные тенденции изменения наблюдаются для некоторых болезней сердца, таких как ревматические заболевания сердиа и гипертоническая болезнь. Снижение смертности от первой из этих патологий, имеющей инфекционный характер, может быть связано с распространением антибиотиков» [Милле и др. 1996: 119]. «Значительны также успехи в борьбе с гипертонической болезнью, хотя снижение смертности от нее, особенно интенсивное в 70е годы, позже замедлилось. В 80-е годы смертность от гипертонии в России снизилась до уровня Франции» (впрочем, здесь же делалась оговорка, что «такая эволюция смертности от гипертонической болезни в России связана больше с изменением практики кодирования причин смерти, чем с реальными изменениями») [Милле и др. 1996: 119].

Если в отношении болезней сердца, даже и отмечая большое отставание России от Франции, авторы исследования указывали и на некоторые противостоящие росту смертности тенденции, то «вторая основная составляющая смертности от сердечнососудистых заболеваний - нарушения мозгового кровообращения - непрерывно росла в течение последних 30 лет, что резко контрастирует с выраженным снижением смертности от этой патологии во Франции» [Милле и др. 1996: 119].

В свете этого рассуждения кажется неожиданным обозначившийся во второй половине 90-х годов рост в России ранее снижавшегося вклада в общую смертность от болезней системы кровообращения ишемической болезни сердца. Сейчас она определяет больше половины стандартизованного коэффициента смертности от болезней системы кровообращения у мужчин и ненамного меньше у женщин, причем тенденция снижения этого вклада пока не просматривается. В западноевропейских странах этот вклад 
существенно меньше и в последние два десятилетия имеет тенденцию к снижению (рисунок 6). Не связно ли это с затянувшейся неспособностью российского общества ограничить действие внешних факторов, меньше зависящих от возраста?

К числу этих факторов относится, в частности, алкоголь. Многочисленные исследования подчеркивают связь чрезмерного потребления алкоголя с преждевременной смертностью от болезней системы кровообращения, однако точный механизм этой связи остается не до конца ясным. Иногда даже высказывается предположение, что эта связь лишь видимость, которая возникает благодаря тому, что часть смертей в результате алкогольных отравлений классифицируется как следствия болезни сердца [Zaridze et al. 2009]. Вместе с тем Леон и соавторы [Leon et al. 2010] по данным ретроспективного исследования смертности мужчин в г. Ижевске в 2003-2005 гг. обнаружили устойчивую статистическую связь между чрезмерным потреблением алкоголя и смертностью от форм ишемической болезни сердца, кроме инфаркта миокарда (коды МКБ I20, I23-I25). Также отмечается, что снижение смертности от болезней системы кровообращения в период антиалкогольной кампании было связано именно с этими формами ишемической болезни.

В западных странах быстро снижается вклад в сердечно-сосудистую смертность болезней сосудов головного мозга - в России это снижение наметилось лишь недавно, и пока этот вклад у нас остается высоким - у женщин, примерно, такой, какой отмечался во Франции в 1980 г., у мужчин - ненамного меньше (рисунок 7).

Соответственно, в России весьма низок вклад всех остальных болезней системы кровообращения, который в других странах все время растет. Правда, после 2000 г. он растет и в России, но отрыв от западноевропейских стран все еще очень велик (рисунок 8).

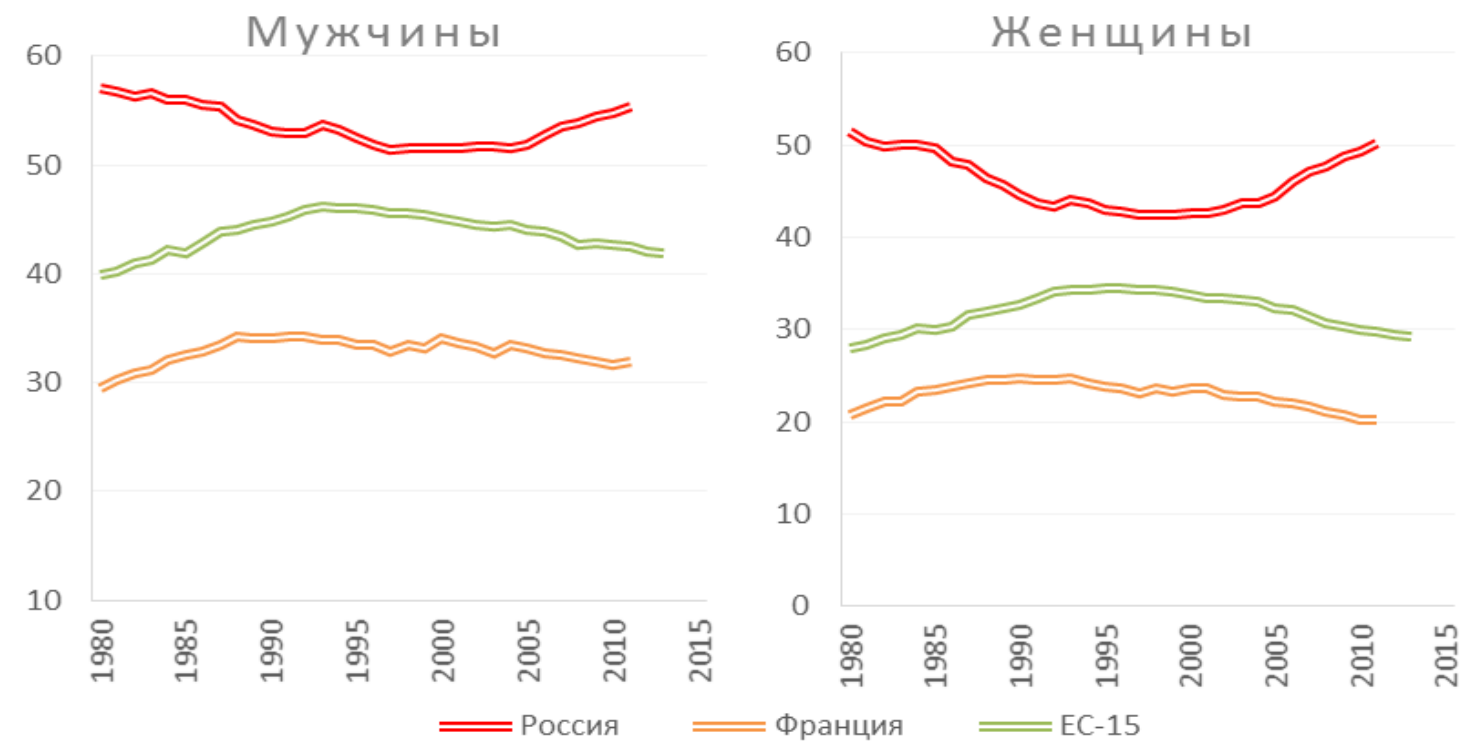

Рисунок 6. Вклад ишемической болезни сердца в стандартизованный коэффициент смертности от болезней системы кровообращения в России, Франции и ЕС-15, \%

Источник: Расчеты авторов по данным [РосБРиС 2015; WНО МD 2015$].$ 


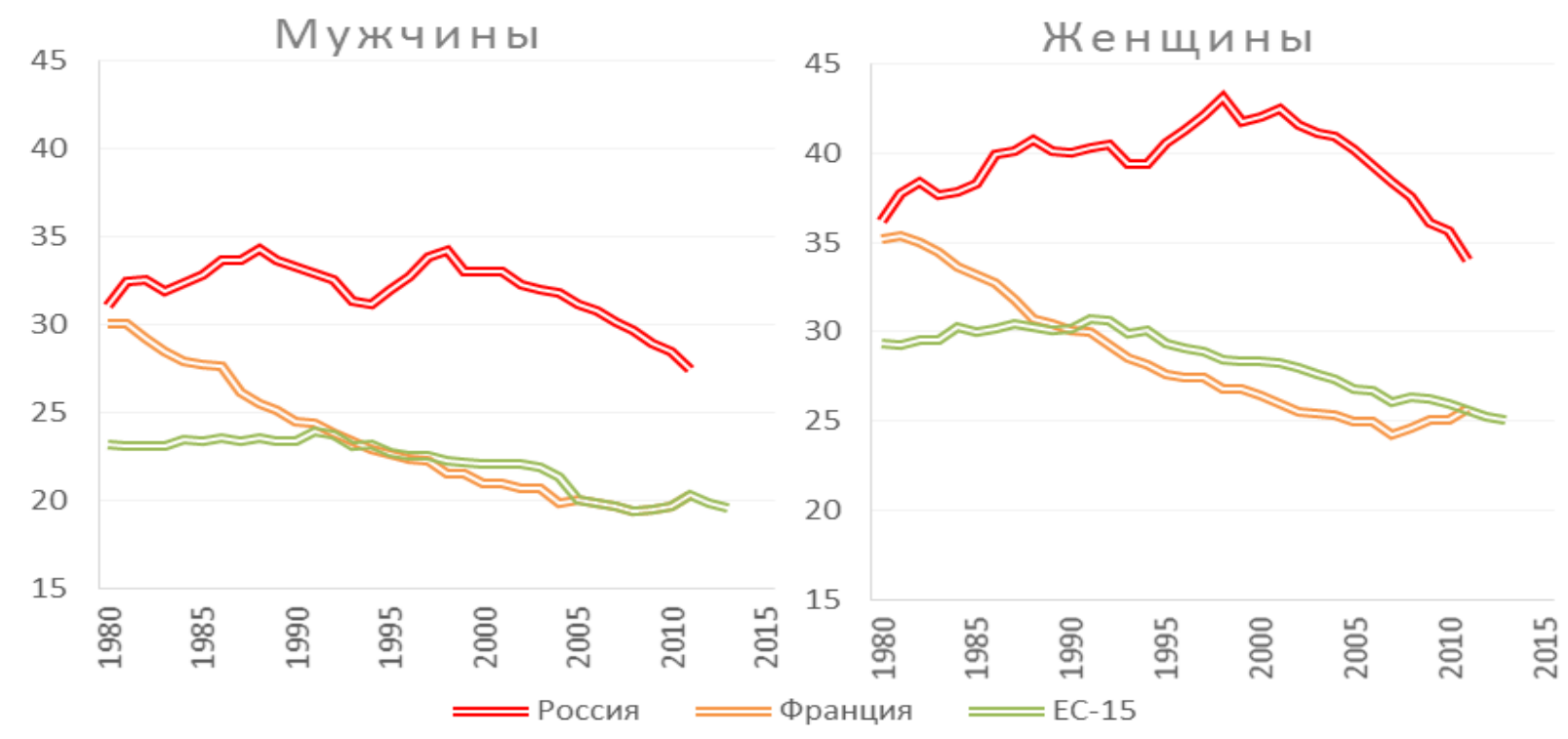

Рисунок 7. Вклад цереброваскулярных болезней в стандартизованный коэффициент смертности от болезней системы кровообращения в России, Франции и ЕС-15, \%

Источник: Расчеты авторов по данным [РосБРиС 2015; WHО МD 2015].

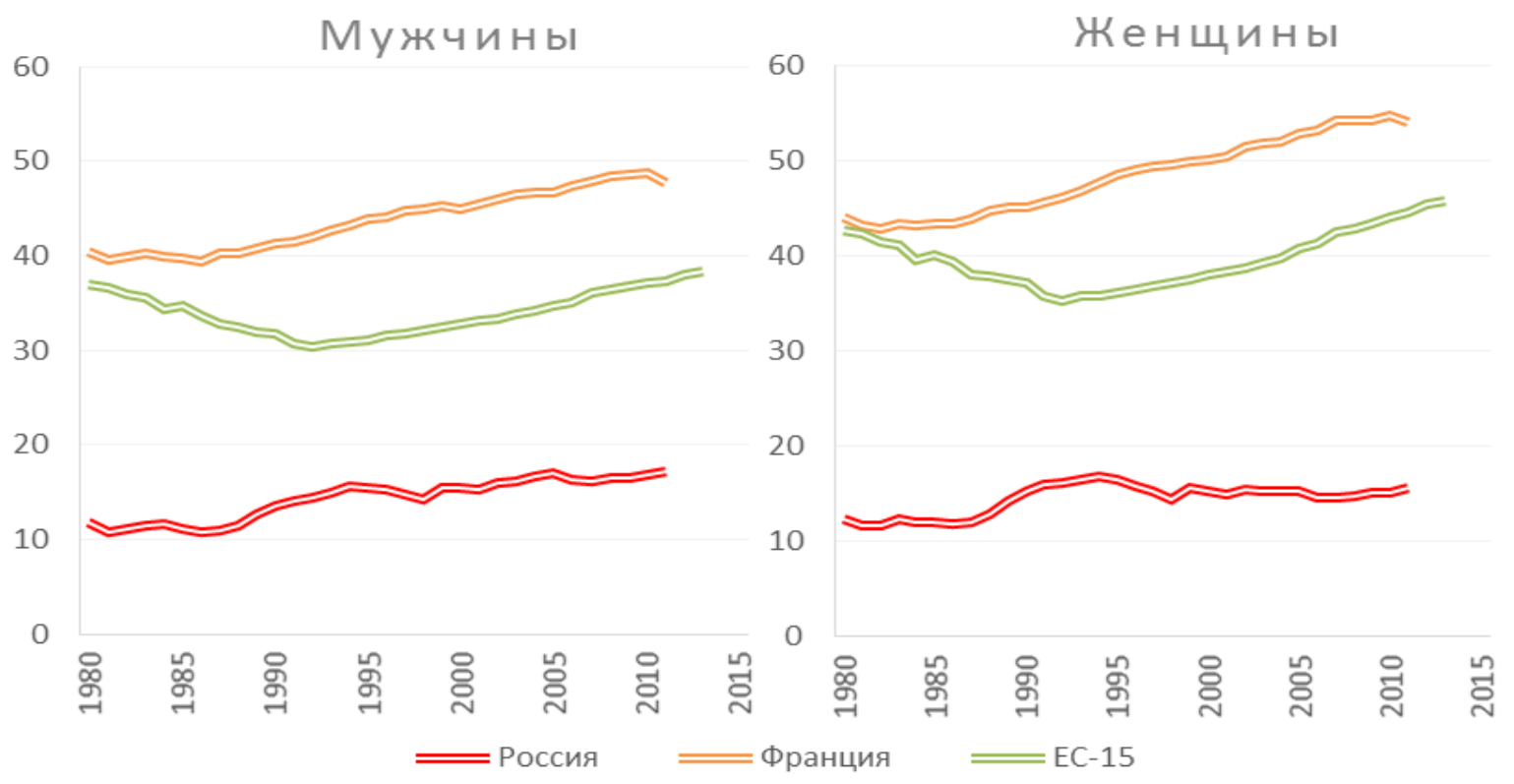

Рисунок 8. Вклад остальных сердечно-сосудистых заболеваний в стандартизованный коэффициент смертности от болезней системы кровообращения в России, Франции и странах ЕC-15, \%

Источник: Расчеты авторов по данным [РосБРиС 2015; WНО МD 2015].

Вклад трех крупных групп причин смерти в общую смертность от болезней системы кровообращения важен не сам по себе, а в связи с возрастом, в котором люди умирают от заболеваний той или иной группы. В России в сравнении с другими странами очень низок средний возраст смерти от всех трех групп сердечно-сосудистых заболеваний, но, кроме того, соотношение между ними не такое, как в странах с низким уровнем смертности. 
Сравнение России и Франции на рисунке 9 показывает, что во Франции рост вклада других болезней системы кровообращения за счет снижения вклада ишемической болезни сердца и цереброваскулярных заболеваний, о чем говорилось выше, сочетается с высоким возрастом смерти от других болезней системы кровообращения, которые в России характеризуются намного более низким (на 8,5 года в 2010 г.) возрастом смерти. При этом в России возраст смерти от них и у мужчин, и у женщин существенно ниже, чем от ишемической болезни сердца или цереброваскулярных заболеваний, тогда как во Франции он, напротив, самый высокий.

\section{Мужчины}

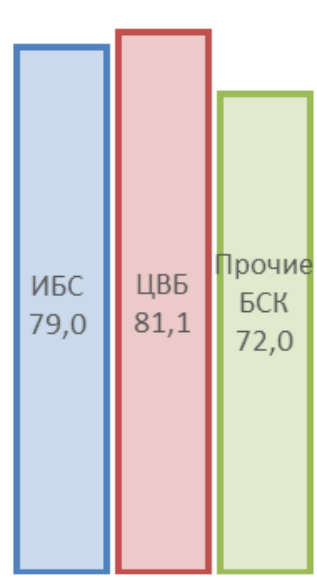

Россия

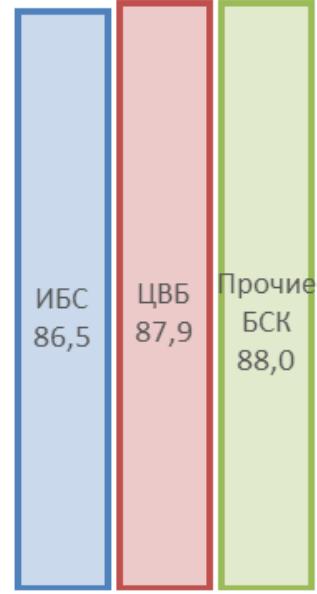

Франция

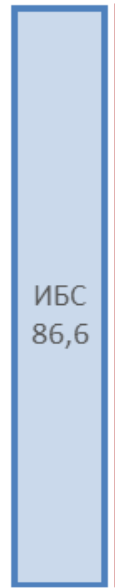

Россия

Женщины

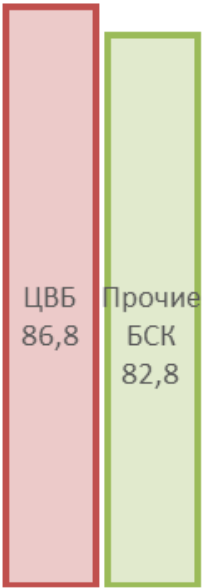

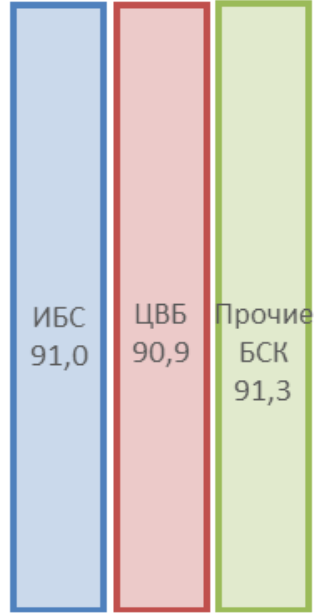

Франция

Рисунок 9. Средний возраст смерти от ишемической болезни сердца, цереброваскулярных заболеваний и прочих болезней системы кровообращения в России и во Франции, 2010 г., лет

Примечание: ИБС - ишемическая болезнь сердиа, ЦВБ - иереброваскулярные заболевания, БСК болезни системы кровообращения.

Источник: Расчеты авторов по данным [РосБРиС 2015; WНО МD 2015].

Из таблицы 3 видно, что самый меньший (хотя все же весьма значительный) отрыв России от других стран по среднему возрасту смерти в 2010 г. был характерен для цереброваскулярных болезней. Для смертности от ишемической болезни, вклад которой велик и имеет тенденцию к росту, и разрыв в среднем возрасте смерти больше, и он растет быстрее, чем в случае цереброваскулярных болезней. Но особенно велик этот разрыв для смертности от всех остальных болезней системы кровообращения, особенно у мужчин. Эта особенность заслуживает отдельного анализа, который выходит за пределы задач этой статьи. Можно лишь предположить, что в России речь чаще идет о тех попадающих в категорию «прочих» заболеваниях, которые больше зависят от условий и образа жизни, например, об алкогольной кардиомиопатии.

На рисунке 10 показан вклад изменений смертности от болезней системы кровообращения и их укрупненных групп в изменения продолжительности жизни в России 
с 1972 г. по периодам роста и сокращения этого показателя. На графике видно, что в результате взаимного погашения этих разнонаправленных изменений прирост продолжительности жизни за счет снижения смертности от болезней системы кровообращения за весь более чем 40 -летний период у женщин составил немногим более 2 лет, а у мужчин - менее полугода, причем вклад цереброваскулярных болезней у женщин и прочих болезней системы кровообращения у мужчин в целом за весь период оказался отрицательным.

Таблица 3. Разница в среднем возрасте смерти от всех причин смерти и от болезней системы кровообращения между Россией и некоторыми странами, лет*

\begin{tabular}{|c|c|c|c|c|c|c|c|c|}
\hline & Германия & Польша & США & Франция & Швеция & Эстония & Чехия & Финляндия \\
\hline \multicolumn{9}{|c|}{ Мужчины } \\
\hline \multicolumn{9}{|c|}{ Все причины смерти } \\
\hline 1970 & 0,66 & $-0,05$ & 0,43 & 1,93 & 3,99 & 1,27 & - & $-2,35$ \\
\hline 1990 & 5,02 & 0,37 & 4,94 & 6,43 & 6,27 & 0,24 & 0,47 & 2,67 \\
\hline 2010 & 11,48 & 5,41 & 9,95 & 12,62 & 12,72 & 5,67 & 8,89 & 10,21 \\
\hline \multicolumn{9}{|c|}{ Ишемическая болезнь } \\
\hline 1970 & $-2,67$ & $-5,06$ & $-0,56$ & $-2,24$ & 3,32 & 1,21 & - & $-5,06$ \\
\hline 1990 & 4,43 & $-5,67$ & 5,86 & 5,05 & 6,25 & 2,00 & 0,14 & 3,16 \\
\hline 2010 & 10,10 & 3,05 & 9,15 & 10,28 & 11,25 & 6,19 & 8,16 & 10,29 \\
\hline \multicolumn{9}{|c|}{ Цереброваскулярные болезни } \\
\hline 1970 & 2,24 & $-2,28$ & 2,24 & 2,41 & 3,85 & 1,01 & - & $-0,74$ \\
\hline 1990 & 4,99 & $-3,74$ & 4,93 & 5,67 & 5,57 & $-0,82$ & 0,56 & 2,19 \\
\hline 2010 & 8,98 & 1,94 & 8,00 & 9,78 & 10,24 & 3,00 & 7,18 & 8,14 \\
\hline \multicolumn{9}{|c|}{ Прочие болезни системы кровообращения } \\
\hline 1970 & 6,20 & 5,81 & 4,31 & 7,10 & 8,66 & 0,17 & - & 5,49 \\
\hline 1990 & 6,83 & 4,35 & 5,13 & 8,29 & 8,93 & $-8,32$ & 2,11 & 3,94 \\
\hline \multirow[t]{2}{*}{2010} & 19,00 & 13,41 & 16,71 & 20,40 & 20,53 & 10,70 & 15,19 & 14,20 \\
\hline & & & & Женщинь & & & & \\
\hline \multicolumn{9}{|c|}{ Все причины смерти } \\
\hline 1970 & $-0,02$ & $-1,18$ & 1,31 & 1,34 & 2,54 & 1,07 & - & $-1,18$ \\
\hline 1990 & 3,53 & 0,17 & 4,00 & 5,39 & 4,59 & 0,34 & $-0,17$ & 2,42 \\
\hline 2010 & 7,03 & 3,75 & 5,54 & 8,90 & 7,65 & 4,89 & 4,89 & 7,26 \\
\hline \multicolumn{9}{|c|}{ Ишемическая болезнь } \\
\hline 1970 & $-2,35$ & $-3,89$ & 0,30 & $-2,27$ & 1,77 & 1,01 & - & $-3,37$ \\
\hline 1990 & 2,02 & $-6,38$ & 3,84 & 3,81 & 3,46 & 0,94 & $-0,93$ & 1,62 \\
\hline 2010 & 6,22 & 2,63 & 5,16 & 8,04 & 6,55 & 5,46 & 4,90 & 7,35 \\
\hline \multicolumn{9}{|c|}{ Цереброваскулярные болезни } \\
\hline 1970 & 0,94 & $-2,79$ & 2,13 & 1,81 & 1,93 & 0,57 & - & $-1,26$ \\
\hline 1990 & 3,99 & $-3,00$ & 4,55 & 5,50 & 4,82 & 0,16 & 0,35 & 2,74 \\
\hline 2010 & 5,63 & 1,34 & 4,80 & 7,40 & 6,58 & 3,03 & 4,34 & 5,89 \\
\hline \multicolumn{9}{|c|}{ Прочие болезни системы кровообращения } \\
\hline 1970 & 4,01 & 3,31 & 4,00 & 5,97 & 6,48 & $-0,45$ & - & 4,15 \\
\hline 1990 & 4,81 & 2,19 & 4,00 & 6,52 & 6,28 & $-8,06$ & 0,59 & 3,87 \\
\hline 2010 & 11,24 & 8,36 & 9,18 & 13,09 & 12,15 & 7,69 & 7,81 & 10,34 \\
\hline
\end{tabular}

* Средний возраст взят из таблиц смертности по причинам смерти и не зависит от возрастного состава населения. Положительные значения в таблице 3 указывают, на сколько лет средний возраст смерти в России меньше, чем в указанной стране, отрицательные - на сколько он больше.

Источник: Расчеты авторов по данным [РосБРиС 2015; WНО МD 2015$].$ 


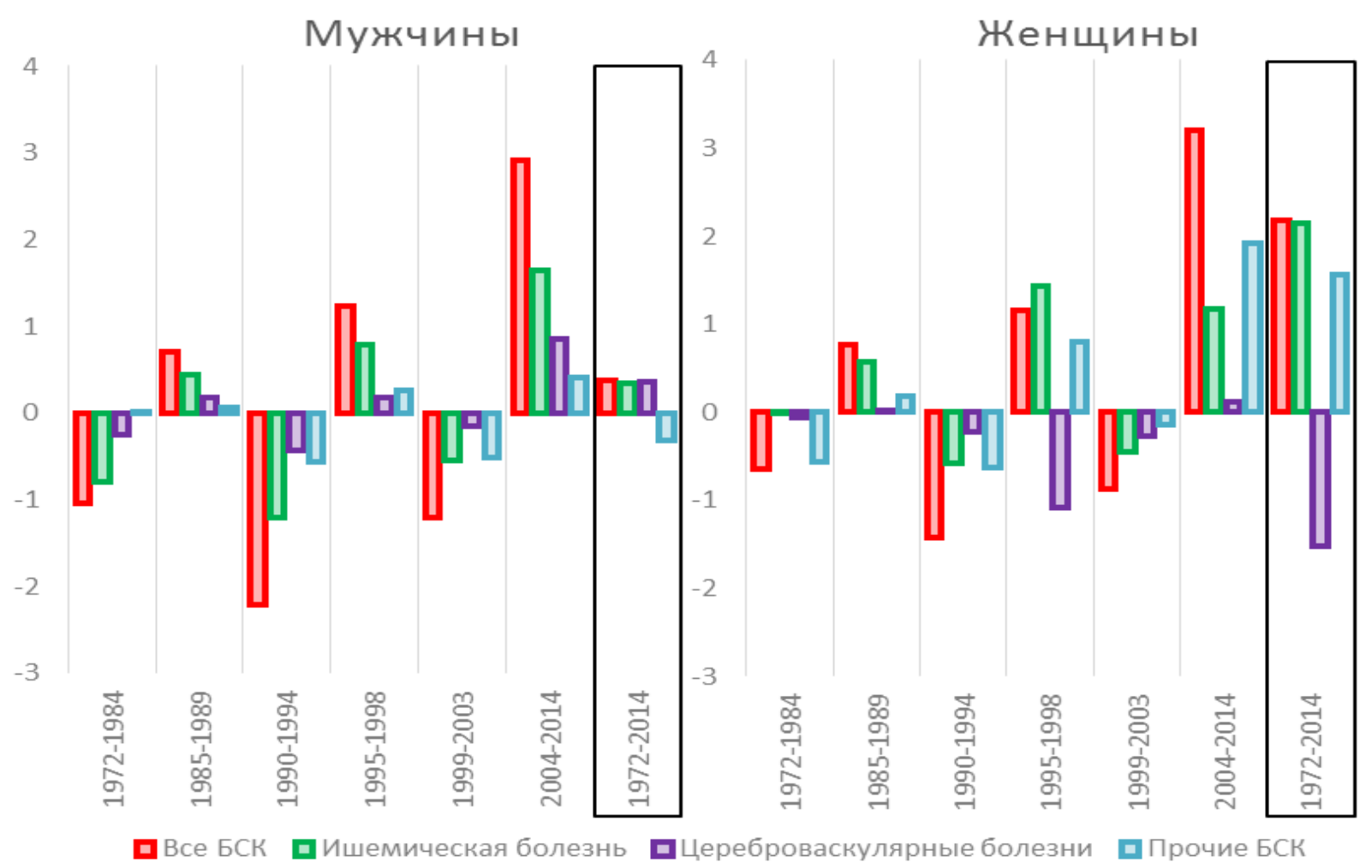

Рисунок 10. Изменения ожидаемой продолжительности жизни при рождении в России в результате изменения смертности от болезней системы кровообращения (БСК) и их отдельных групп за 1972-2014 гг.

Источник: Расчеты авторов по данным [РосБРиС 2015; WНО МD 2015].

\section{ВОЗРАСТНАЯ МОДЕЛЬ СЕРДЕЧНО-СОСУДИСТОЙ СМЕРТНОСТИ В РОССИИ}

Низкий возраст смерти от болезней системы кровообращения и их укрупненных групп в России - свидетельство общего застоя возрастной модели смертности от этих болезней - и сама эта модель, и ее динамика в России разительно отличаются от того, что можно видеть в последние десятилетия в странах «кардиоваскулярной революции», в частности в странах Западной Европы (рисунок 11).

Как следует из рисунка 11 , в России у мужчин табличное число смертей $\left(d_{x}\right)$ от сердечно-сосудистых заболеваний, не зависящее от возрастной структуры, начинает быстро нарастать уже после достижения 25-летнего возраста, основная масса умирающих от этих причин концентрируется в возрастах до 70-75 лет, после чего их доля даже сокращается. В странах Западной Европы рост начинается позже (российские показатели, фиксируемые в 25 лет, там не достигаются и к 40 годам), кривые поднимаются гораздо менее круто, но зато этот подъем длится до самых поздних возрастов, так что пик умерших от болезней системы кровообращения приходится не на 70-75 лет, как в России, а ближе к 90 годам. На нашем графике, где возрастная шкала заканчивается открытым возрастным интервалом 85 лет и старше, максимальное число умерших мужчин и женщин в ЕС-15 приходится на открытый возрастной интервал. У российских женщин возрастное 
распределение смертей от болезней системы кровообращения больше похоже на западноевропейское, но все же тоже сильно сдвинуто в сторону более молодых возрастов.

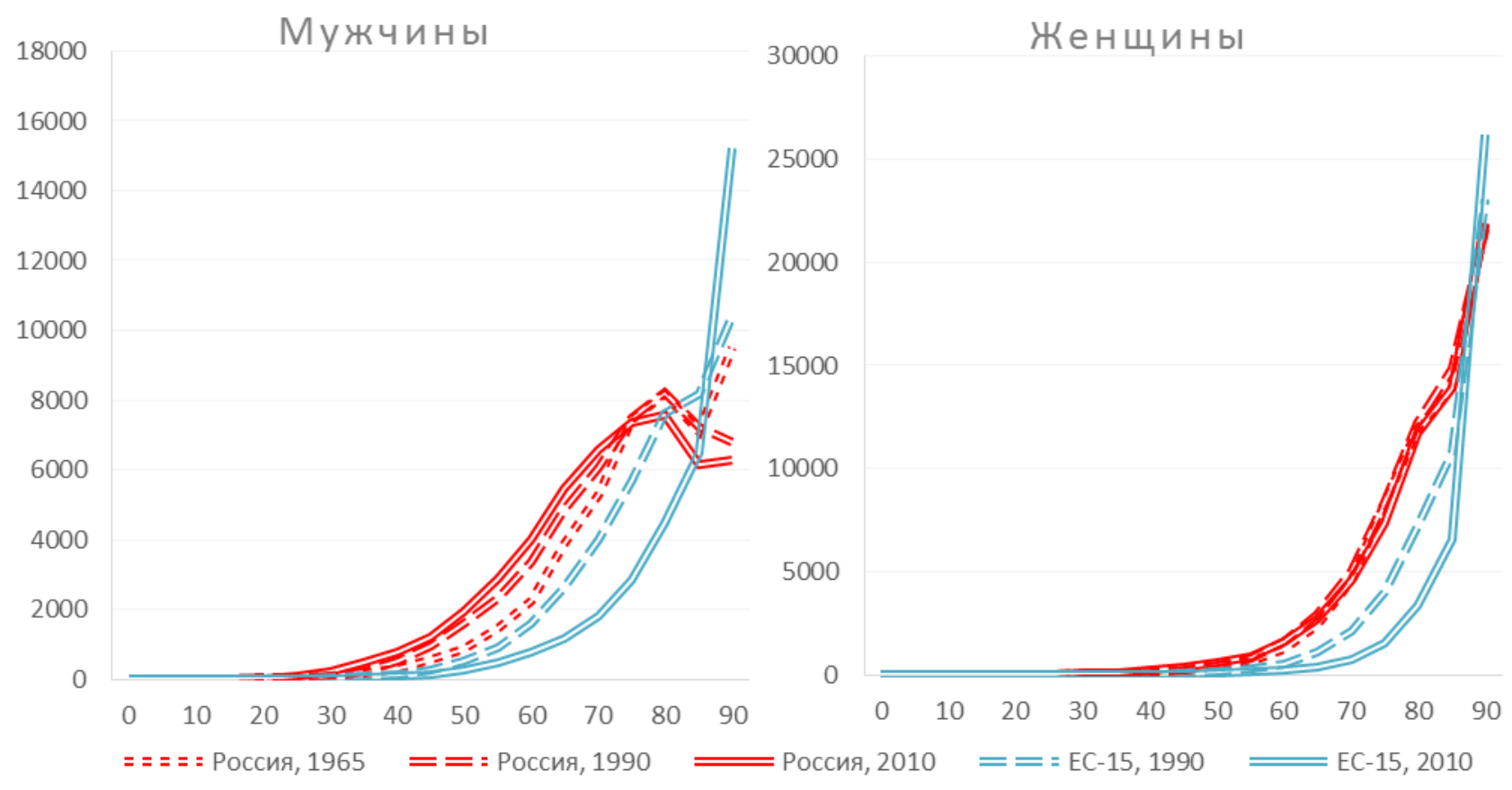

Рисунок 11. Возрастное распределение табличных чисел умирающих $\left(d_{x}\right)$ от болезней системы кровообращения в России и в странах ЕС-15

Источник: Расчеты авторов по данным [РосБРиС 2015; WНО МD 2015].

При этом кривые для стран ЕС-15 демонстрируют выраженную тенденцию сдвигаться вниз и вправо, «прогибаясь» в сторону правого нижнего угла графика. При сравнении кривых 1990 и 2010 г. ясно видно, что правый конец кривых 2010 г. и у мужчин, и у женщин уверенно устремляется вверх, свидетельствуя о смещении все большего числа смертей от сердечно-сосудистых заболеваний к более поздним возрастам. В России же у мужчин кривые вообще прогнуты не вправо, а влево, свидетельствуя о высокой смертности в средних возрастах, при этом кривая 2010 г. хуже кривой 1990 г., а та в свою очередь хуже кривой 1965 г. Женские кривые ближе к западноевропейским, но тоже сильно смещены влево. При этом для них не характерны ни свидетельствующий о прогрессе сдвиг вправо, который демонстрируют европейские кривые, ни говорящий о регрессе сдвиг влево, как у российских мужских кривых; скорее, можно говорить о полном застое на протяжении почти пяти десятилетий.

На рисунке 12 представлена динамика возрастных коэффициентов смертности от болезней системы кровообращения в России для 4 наиболее подверженных смертности от болезней системы кровообращения групп возрастов за период с 1970 г. Видно, что самые большие колебания сердечно-сосудистой смертности характерны для более молодых возрастов, тогда как старшие возрастные группы менее подвержены таким колебаниям. 


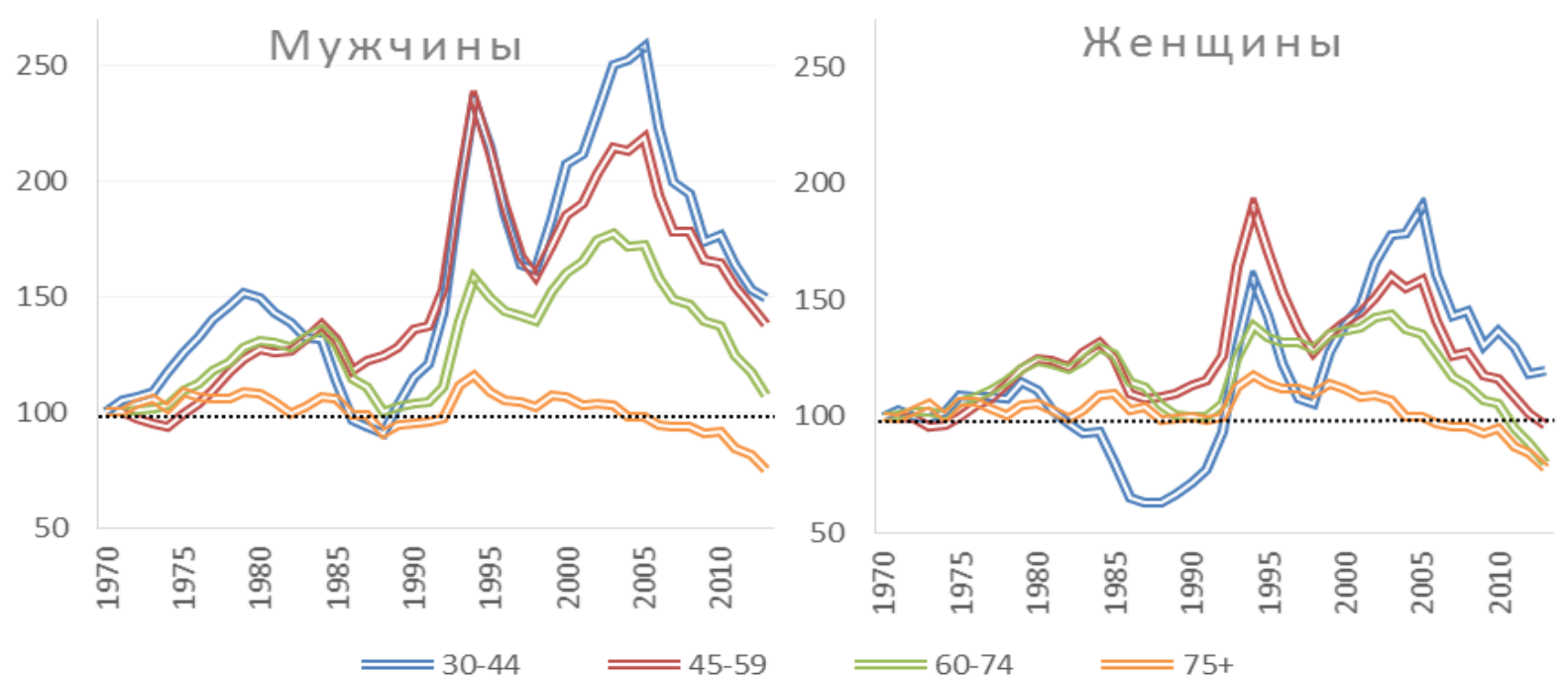

Рисунок 12. Динамика возрастных коэффициентов смертности (30-44, 45-59, 60-74 и 75 лет и старше) от болезней системы кровообращения в России, 1970 г. $=100 \%$

Источник: Расчеты авторов по данным [РосБРиС 2015].

Несмотря на значительное снижение смертности во всех возрастных группах на протяжении последних 10 лет, уровень мужской смертности от болезней системы кровообращения в возрастах до 75 лет, а женской - до 45 лет остается все еще выше показателей, достигнутых в 1970 г.

Таблица 4. Избыточные табличные числа мужских и женских смертей $\left(d_{x}\right)$ от болезней системы кровообращения в возрасте 30-85 лет в России в сравнении с некоторыми странами, на 100000 человек, умирающих во всех возрастах и от всех причин

\begin{tabular}{|c|c|c|c|c|c|c|c|c|c|c|}
\hline & \multicolumn{5}{|c|}{ Мужчины } & \multicolumn{5}{|c|}{ Женщины } \\
\hline & $\begin{array}{c}\text { Япония, } \\
2013\end{array}$ & $\begin{array}{c}\text { Франция, } \\
2011\end{array}$ & $\begin{array}{l}\text { США, } \\
2010\end{array}$ & $\begin{array}{c}\text { Чехия, } \\
2013\end{array}$ & $\begin{array}{c}\text { Эстония, } \\
2012\end{array}$ & $\begin{array}{c}\text { Япония, } \\
2013\end{array}$ & $\begin{array}{c}\text { Франция, } \\
2011\end{array}$ & $\begin{array}{l}\text { США, } \\
2010\end{array}$ & $\begin{array}{l}\text { Чехия, } \\
2013\end{array}$ & $\begin{array}{c}\text { Эстония, } \\
2012\end{array}$ \\
\hline $30-34$ & 361 & 373 & 320 & 346 & 322 & 105 & 108 & 80 & 112 & 104 \\
\hline $35-39$ & 591 & 617 & 533 & 604 & 449 & 182 & 183 & 134 & 169 & 123 \\
\hline $40-44$ & 862 & 904 & 757 & 827 & 591 & 275 & 284 & 197 & 260 & 247 \\
\hline $45-49$ & 1334 & 1404 & 1115 & 1181 & 870 & 406 & 430 & 268 & 362 & 322 \\
\hline $50-54$ & 1979 & 2037 & 1608 & 1631 & 1034 & 602 & 624 & 385 & 484 & 507 \\
\hline $55-59$ & 2822 & 2879 & 2281 & 2000 & 1441 & 1112 & 1146 & 803 & 873 & 743 \\
\hline $60-64$ & 4031 & 4147 & 3377 & 2488 & 1427 & 1931 & 1985 & 1447 & 1338 & 1208 \\
\hline $65-69$ & 4333 & 4481 & 3458 & 1915 & 816 & 3013 & 3112 & 2284 & 1783 & 1717 \\
\hline $70-74$ & 5520 & 5636 & 4434 & 2408 & 166 & 5738 & 5758 & 4670 & 3396 & 3061 \\
\hline $75-79$ & 4619 & 4664 & 3434 & 434 & -2 & 8076 & 8123 & 6681 & 3909 & 2900 \\
\hline $80-84$ & 2036 & 2059 & 1131 & -2300 & -1715 & 9199 & 9166 & 7965 & 1962 & 386 \\
\hline Всего: & 28489 & 29200 & 22449 & 11536 & 6399 & 30639 & 30918 & 24915 & 14648 & 11318 \\
\hline Чис. & избыточ & смерте & & лее 5000 & 30 & $0-5000$ & 1000 & 3000 & мене & 1000 \\
\hline
\end{tabular}

Источник: Расчеты авторов по данным [РосБРиС 2015; WHO MD 2015].

Недостатки возрастной модели российской смертности от болезней системы кровообращения хорошо видны в таблице 4, которая позволяет сравнить распределение смертей по возрасту в России и некоторых других странах и выделить «возрастные группы риска» для населения России, указав для каждой из них избыточное по сравнению с этими странами число смертей. 
К примеру, цифра в нижней строке столбца 2 таблицы 4 показывает, что в 2013 г. в России, по сравнению с Японией, из каждых 100000 мужских смертей во всех возрастах более 28 тыс. смертей, произошедших в возрастах 30-84 года от болезней системы кровообращения, можно было считать избыточными, в Японии в этих возрастах их бы не было. При этом особенно велико число избыточных смертей в возрасте 70-74 года, в то время как избыточная смертность в возрастах до 45 лет, хотя она есть и в этих возрастах, все же сравнительно невелика. Таким же образом можно анализировать любой столбец таблицы.

\section{РЕГИОНАЛЬНЫЕ ОСОБЕННОСТИ СМЕРТНОСТИ ОТ БОЛЕЗНЕЙ СИСТЕМЫ КРОВООБРАЩЕНИЯ В РОССИИ}

Анализ смертности от болезней системы кровообращения в России не может обойтись без рассмотрения региональных особенностей, которые проявляются на фоне общей картины, характерной для всей страны.

Наиболее неблагоприятная ситуация в 2013 г. складывалась в районах Дальнего Востока, некоторых регионах Восточной Сибири (Тыва, Иркутская область, ЯНАО), а также на севере и северо-западе Европейской части России и Приуралья (Пермский край). Напротив, регионы с самой низкой смертностью от болезней системы кровообращения города федерального значения (Москва и Санкт-Петербург), юг Европейской части России, Поволжье и некоторые регионы Западной Сибири (рисунки 13 и 14).

На рисунках 15 и 16 показаны изменения уровня смертности от болезней системы кровообращения мужчин и женщин в регионах России. За прошедшее десятилетие (20032013 гг.) эти изменения во всех субъектах Российской Федерации носили позитивный характер, хотя их величина варьировалась от региона к региону. В целом стандартизованный коэффициент смертности от болезней системы кровообращения в России сократился на 36,3\% у мужчин и на $37,8 \%$ у женщин. Наиболее высокие темпы снижения смертности были в первую очередь зафиксированы в тех регионах, которые в 2003 г. имели наиболее высокие показатели смертности от болезней системы кровообращения, - преимущественно регионы, расположенные вокруг Москвы и СанктПетербурга. Некоторым из этих регионов к 2013 г. удалось существенно улучшить свои относительные позиции (Ивановская, Смоленская, Ленинградская, Липецкая, Курская и Тамбовская области). Вместе с тем отметим, что во всех этих областях (за исключением Ленинградской) резко возросла доля умерших в возрасте старше 80 лет от причины смерти «старость», что может свидетельствовать не столько о реальных успехах в снижении сердечно-сосудистой смертности, сколько об изменениях в региональных практиках кодирования причин смерти (подробнее об этом см. ниже). Высокие темпы снижения смертности от болезней системы кровообращения наблюдались в Москве и СанктПетербурге, что дополнительно усилило их позиции. Скромные темпы снижения смертности от БСК были присущи целому ряду регионов Дальнего Востока (Чукотский АО, Республика Саха, Магаданская область и Еврейская автономная область) и Сибири (ЯНАО, Республика Алтай, Новосибирская и Омская области). 


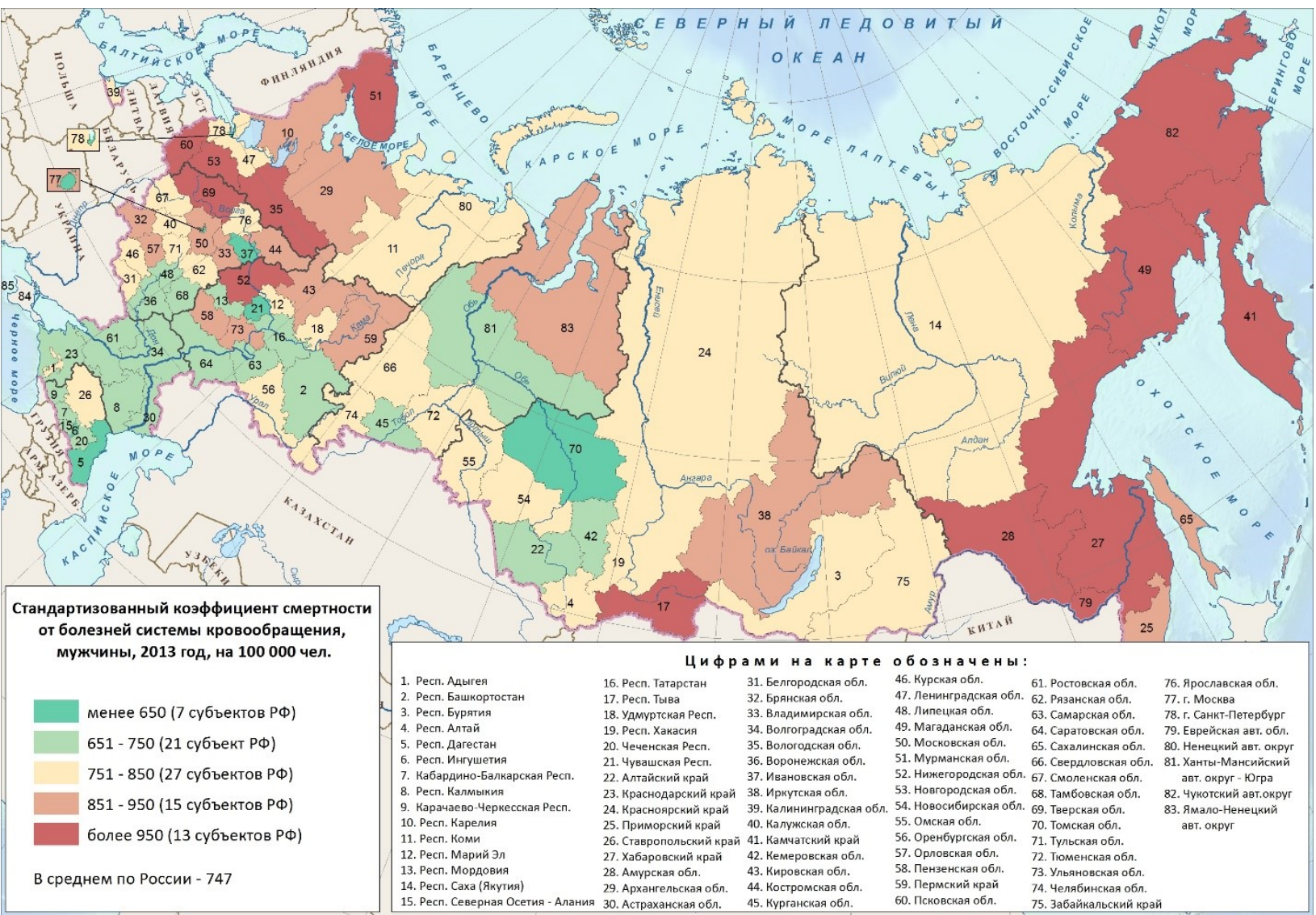

Рисунок 13. Смертность от болезней системы кровообращения, мужчины, 2013

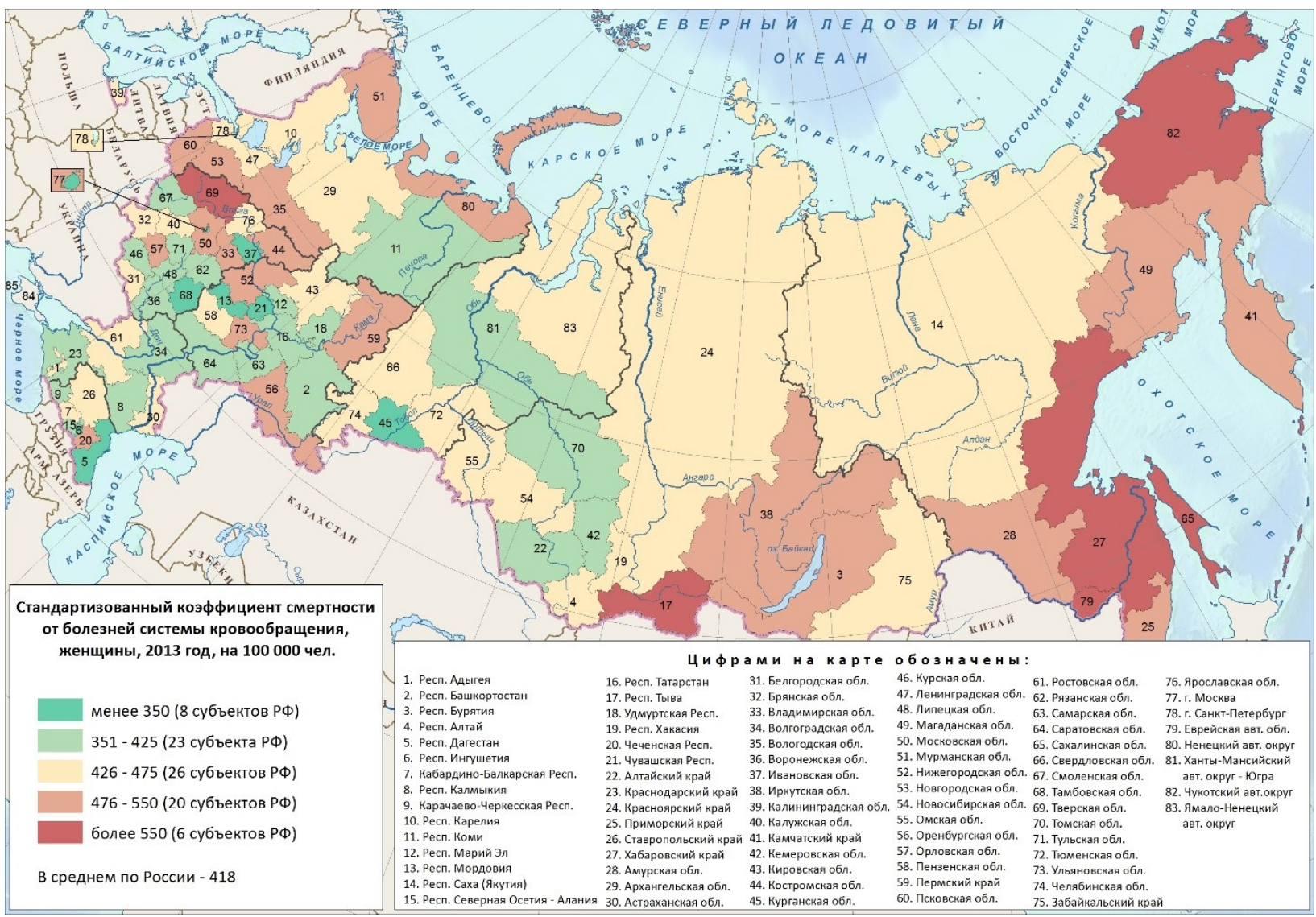

Рисунок 14. Смертность от болезней системы кровообращения, женщины, 2013 


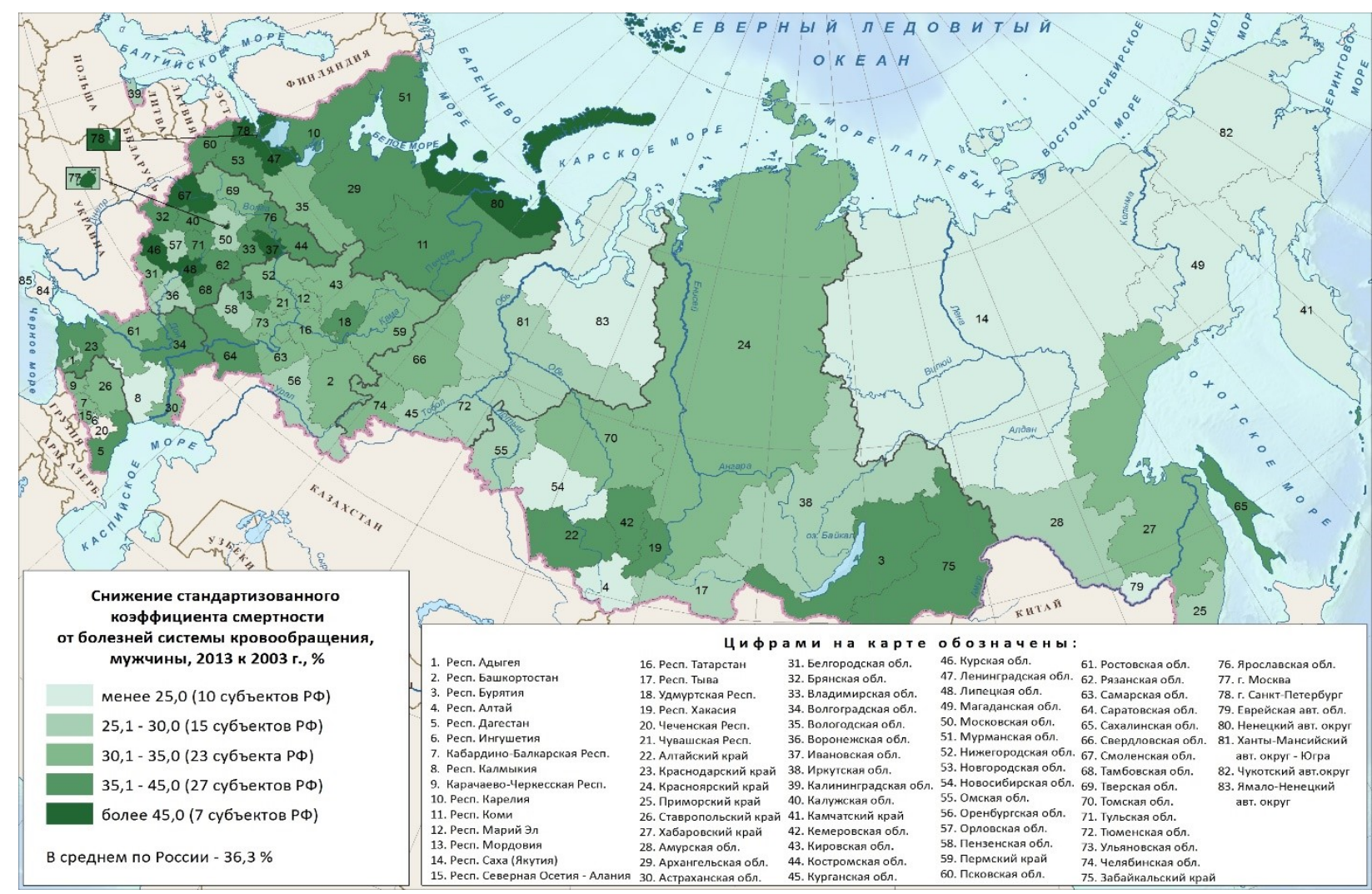

Рисунок 15. Динамика смертности от болезней системы кровообращения, мужчины, 2003-2013

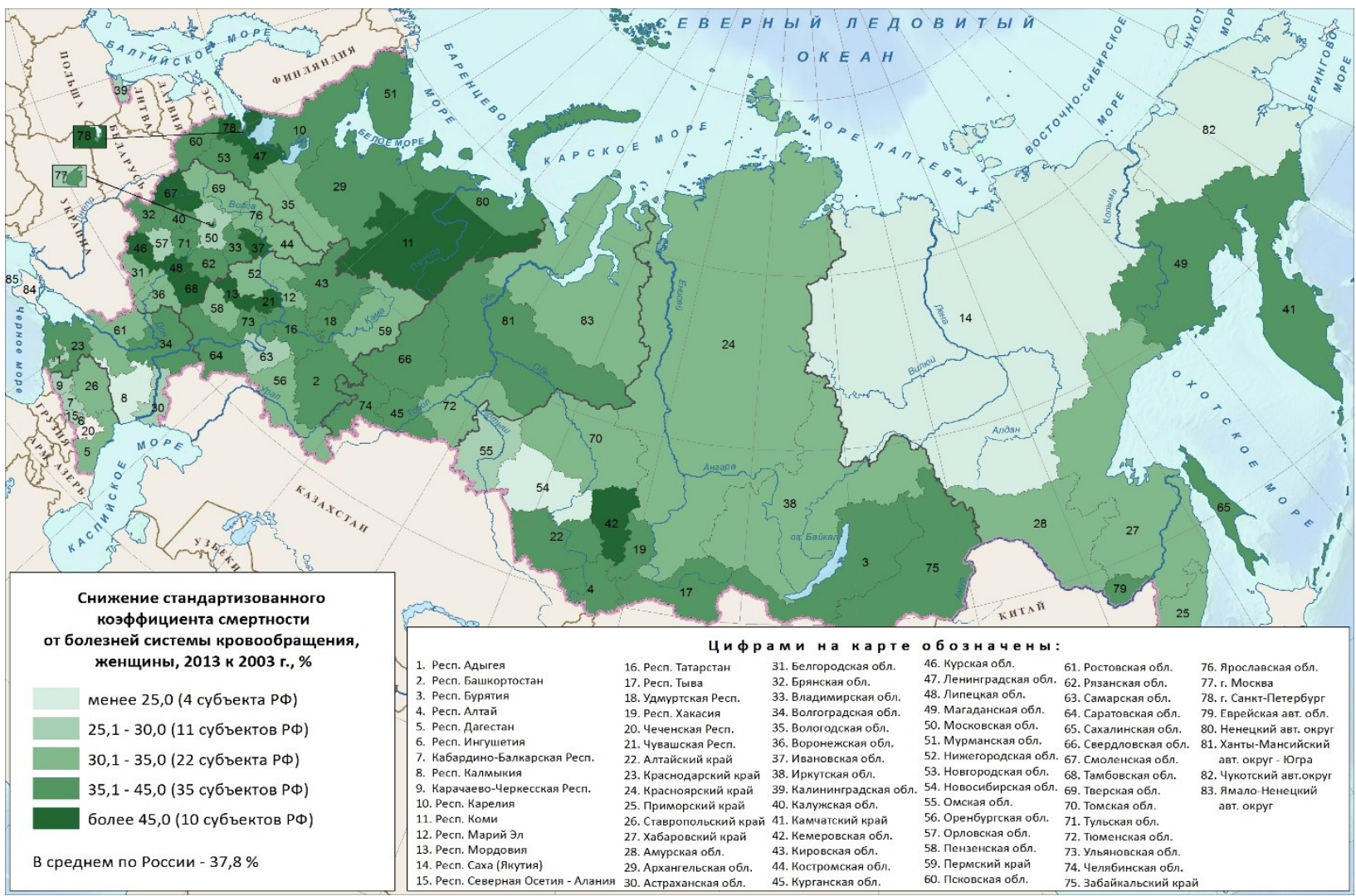

Рисунок 16. Динамика смертности от болезней системы кровообращения, женщины, 2003-2013 


\section{ГИПЕРДИАГНОСТИКА ИЛИ НЕДООЦЕНКА СЕРДЕЧНО-СОСУДИСТОЙ СМЕРТНОСТИ?}

Возможности анализа уровня и тенденций смертности от болезней системы кровообращения существенно зависят от качества кодирования причин смерти при заполнении медицинского свидетельства о смерти. Это качество в России далеко не безупречно.

Зачастую умершие в старших возрастах при жизни имели несколько заболеваний, каждое из которых в какой-то мере могло привести к смерти. В процессе подготовки медицинского свидетельства о смерти, являющегося основным источником статистической информации, врач должен из совокупности возможных причин выбрать первоначальную (основную) причину. Для этих целей разработаны соответствующие рекомендации как на федеральном уровне, так и в регионах. Кроме рекомендаций, существует мнение врача и практика диагностики и кодирования - врач нередко выбирает не самый «правильный», а самый привычный диагноз, не вызывающий вопросов у родственников умершего или у руководства лечебного учреждения. В России таким диагнозом долгое время оставались болезни системы кровообращения, считающиеся естественной причиной смерти в старости, что дало повод экспертному сообществу говорить о гипердиагностике сердечнососудистых причин смерти. Указания на «кардиологические приписки» встречаются и сейчас [Какорина 2013].

В то же время есть основания опасаться и недоучета сердечно-сосудистой смертности. В марте 1989 г. коллегия Министерства здравоохранения СССР в целях борьбы с завышенной смертностью от сердечно-сосудистых болезней по инициативе министра Е.И. Чазова приняла «Указания о порядке установления причины смерти при основных заболеваниях болезней органов кровообращения и записи во врачебном свидетельстве о смерти». Пятнадцатый пункт «Указаний...» состоял в том, что «умершим вне стационара в возрасте старше 80 лет при отсутствии в медицинской документации указаний на заболевания, способные вызвать смерть, при отсутствии подозрения на насильственную смерть, в случаях, когда патологоанатомическое исследование не проводилось, выдается врачебное свидетельство о смерти или фельдшерская справка, где в качестве причины смерти указывается "старость"». Отметим, что постановка диагноза "старость" допускается только после 80 лет и данная причина смерти относится к группе "Симптомы, признаки и отклонения от нормы, выявленные при клинических и лабораторных исследованиях, не классифицированные в других рубриках" и по существу означает, что точная причина смерти не установлена.

Рост числа умерших и коэффициента смертности от старости не заставил себя ждать (рисунок 17). К середине 2000-х годов указание «старости»в качестве первоначальной причины смерти стало значительно более редким, но, как оказалось, ненадолго. В последнее несколько лет, особенно с 2012 г., число умерших от старости неуклонно растет в унисон со снижением смертности от болезней системы кровообращения у лиц старше 80 лет. К примеру, в 2012 г. 11,8\% умерших в возрасте 80 лет и старше скончались с диагнозом «старость», 72,3\% - умерли от сердечно-сосудистых болезней. К 2014 г. доля умерших с 
диагнозом «старость» составила уже 18,7\% (плюс 6,9 п.п.), а от сердечно-сосудистых болезней - 61,2\% (минус 11,1 п.п.).

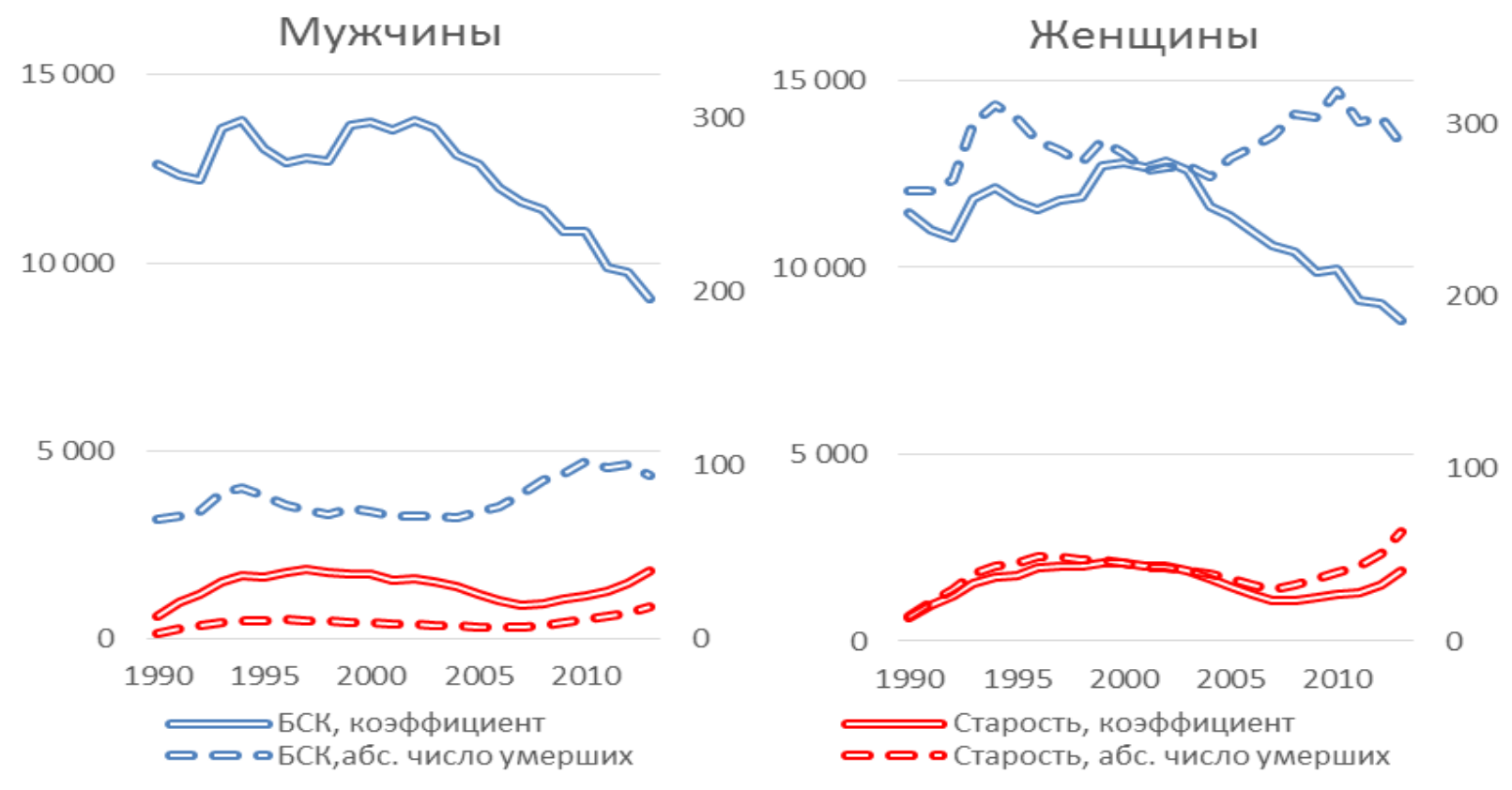

Рисунок 17. Уровень смертности от болезней системы кровообращения (БСК) и от «старости» в возрасте 80 лет и старше, на 100000 человек (левая ось) и абсолютное число умерших от БСК и старости в возрасте 80 лет и старше, тыс. человек (правая ось)

Анализ смертности по причинам смерти за последние годы показывает, что Указ Президента «О совершенствовании государственной политики в сфере здравоохранения», ставивший целью снижение общих коэффициентов смертности от ряда причин смерти, в том числе от болезней системы кровообращения, может вести к тому, что некоторые субъекты РФ, стремясь достичь целевых показателей смертности, меняют практику кодирования причин смерти, о чем нам уже приходилось писать [Вишневский, Андреев, Тимонин 2015].

Указ вышел в мае 2012 г. С 2012 по 2014 г. общее число умерших в России уменьшилось на 1,5\%. Это уменьшение затронуло не все субъекты Федерации, в части из них число умерших росло. Соответствующий показатель по регионам колеблется от $-15 \%$ в Ненецком автономном округе и -8,7\% в Магаданской области до 3,5\% в ХантыМансийском автономном округе - Югре. Если исключить регионы с крайними показателями, то в 77 из 83 субъектов Федерации изменения лежат в интервале от -9\% до $2 \%$. Но ситуация с сердечно-сосудистыми болезнями выглядит иначе. По России в целом число умерших от них снизилось на 10,9\%, но при этом число умерших от всех остальных причин выросло на 10,2\%. Если же обратиться к региональным показателям, то бросается в глаза, что наибольшее снижение числа смертей от сердечно-сосудистых болезней наблюдается там, где более всего выросла смертность от остальных причин при почти неизменном общем числе умерших (таблица 5). 
В Москве и Санкт-Петербурге число умерших от сердечно-сосудистых болезней снизилось на 3,0 и 7,2\%, а от остальных причин выросло на 3,4 и 3,6\% соответственно.

Таблица 5. Изменение числа умерших от всех причин смерти, от болезней системы кровообращения и от всех остальных причин смерти, 2012-2014, \%

\begin{tabular}{l|c|c|c}
\hline & Все причины & $\begin{array}{c}\text { Болезни системы } \\
\text { кровообращения }\end{array}$ & $\begin{array}{c}\text { Все остальные } \\
\text { причины }\end{array}$ \\
\hline Ростовская область & 0,2 & $-31,4$ & 52,7 \\
Белгородская область & 0,0 & $-20,8$ & 45,2 \\
Республика Марий Эл & $-0,4$ & $-30,3$ & 33,2 \\
Владимирская область & $-2,0$ & $-22,2$ & 31,4 \\
Ярославская область & $-2,2$ & $-23,8$ & 28,4 \\
Брянская область & $-2,9$ & $-25,9$ & 38,9 \\
Тульская область & $-4,8$ & $-30,1$ & 31,2 \\
\hline
\end{tabular}

Выросло и число умерших с диагнозом «старость», доля умерших с этим диагнозом с 2012 по 2014 г. выросла с 11,8 до 18,7\% и необычайно сильно варьировалась по регионам (рисунки 18а и 18б). В Башкортостане и Мордовии так была определена причина более половины смертей в возрастах старше 80 лет. В Санкт-Петербурге этот диагноз не встречался, в Москве доля умерших от старости была менее $0,1 \%$. Но в 20 субъектах Федерации доля умерших от старости в возрастах 80 лет и старше в 2012 г. превысила 20\%. В 2014 г. число таких территорий увеличилось до 31. В Костромской, Свердловской, Брянской, Белгородской и Ростовской областях рост доли умерших с диагнозом "старость" составил от 21 до 49 процентных пункта, а уменьшение доли умерших с кардиоваскулярным диагнозом составило от 22 до 49 пунктов. В Республике Алтай, ХантыМансийском автономном округе, Пермском крае, Оренбургской, Амурской, Астраханской областях рост доли умерших с диагнозом "старость" составил от 12 до 21 процентных пункта, а уменьшение доли кардиоваскулярных диагнозов - от 9 до 21 пункта.

Реакцией Министерства здравоохранения РФ на столь «неожиданный» рост смертности от старости стало письмо, направленное в конце 2014 г. в адрес руководителей органов исполнительной власти в субъектах РФ в сфере здравоохранения с разъяснениями, что термин «старость» относится к неточно обозначенным состояниям и критериями его использования в качестве первоначальной причины смерти являются: «возраст старше 80 лет, отсутствие в медицинской документации указаний на хронические заболевания, травмы и их последствия, способные вызвать смерть, отсутствие подозрений на насильственную смерть».

Существование в недавнем прошлом гипердиагностики болезней системы кровообращения в качестве причины смерти весьма вероятно. Возможно, что субъекты Федерации, стремясь достичь целевых показателей смертности, стараются от нее избавиться и меняют практику кодирования причин смерти. Но совершенно не ясно, насколько столь радикальные изменения оправданы. Всего число умерших от болезней системы кровообращения снизилось за 2 года на 15\% и более в 19 субъектах Федерации. 


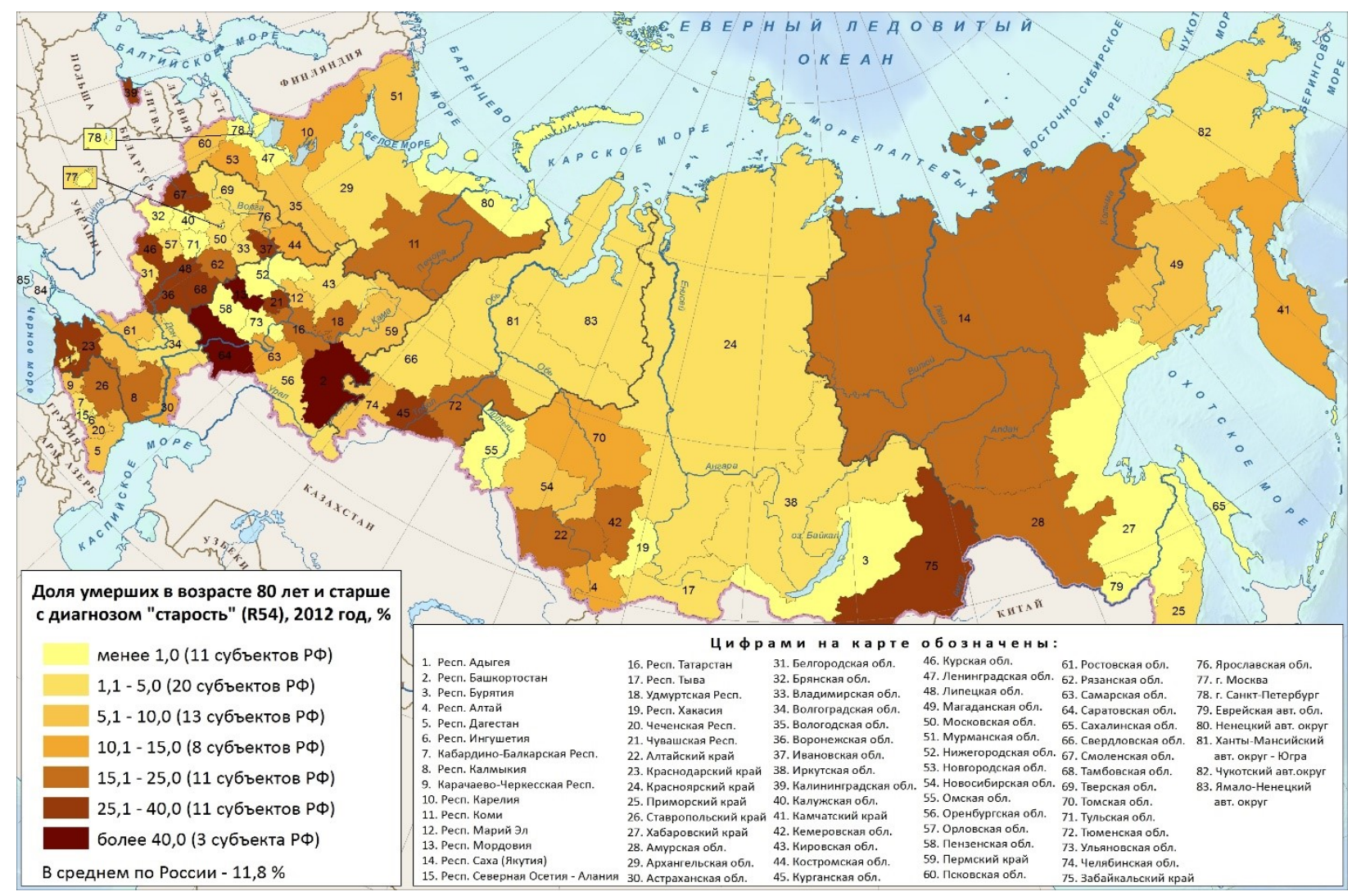

a. 2012 г.

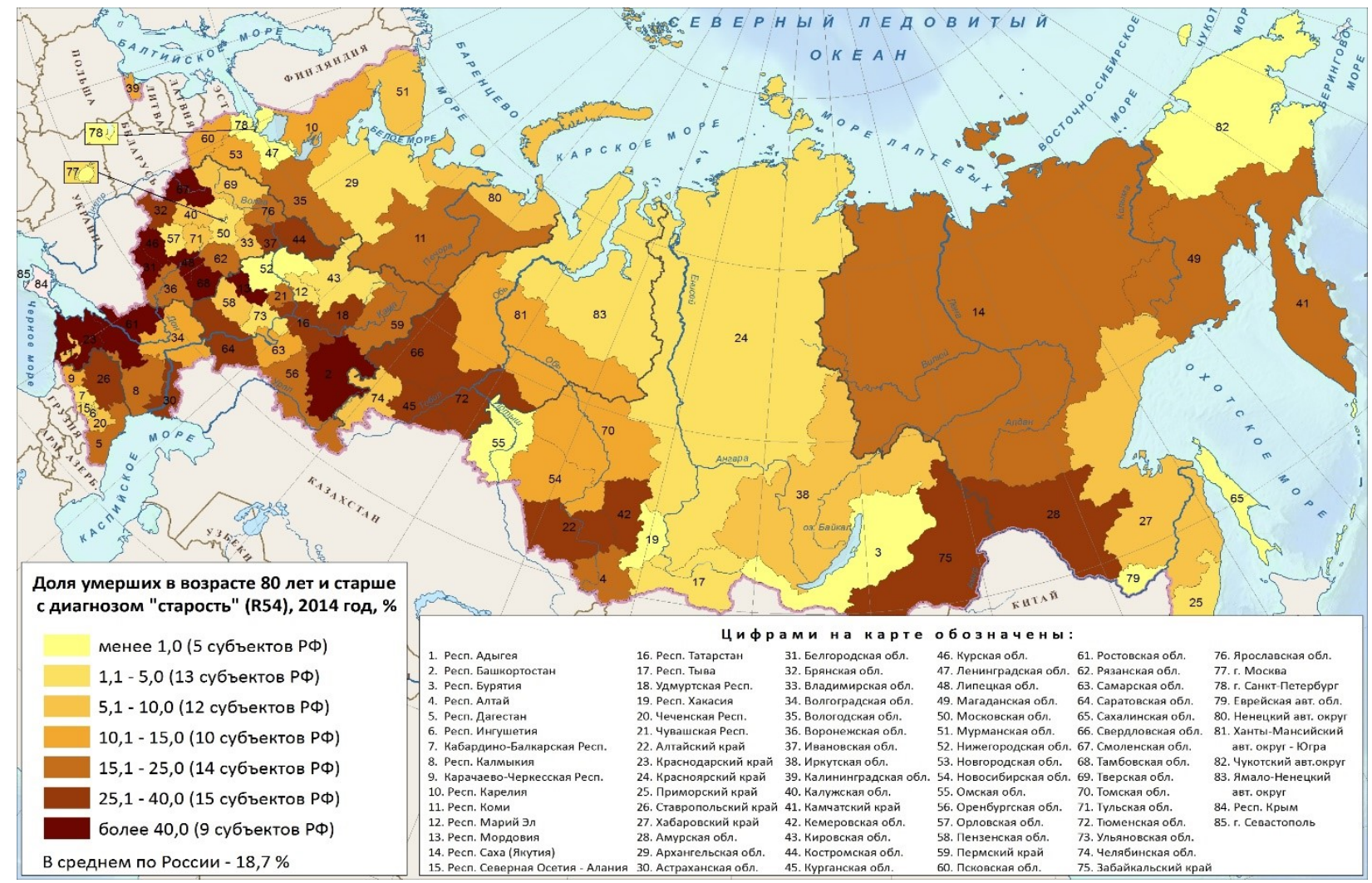

\section{б. 2014 г.}

Рисунок 18. Доли умерших в возрасте 80 лет и старше с диагнозом «старость», 2012 и 2014 годы 
Возможно, изменение практики кодирования причин смерти в принципе правомерно, но оно должно быть обосновано. Вопрос требует специального изучения, и принципы кодирования должны быть унифицированы, отсутствие единообразия серьезно осложняет анализ [Данилова 2015; Danilova et. al 2016]. В любом случае снижение показателя смертности от сердечно-сосудистых болезней в регионах в результате изменения практики кодирования причин смерти не следует смешивать с реальными успехами в борьбе с сердечно-сосудистой патологией.

\section{ЛИТЕРАТУРА}

Бирюков В.А. (1979). Сердечно-сосудистые заболевания и продолжительность жизни // Продолжительность жизни: анализ и моделирование. Сборник статей / Под ред. Е.М. Андреева, А.Г. Вишневского. М.: Статистика.

Вишневский А.Г. (1986). Человеческий фактор в демографическом измерении // Коммунист. 17: 69-80.

Вишневский А.Г. (2014). Смертность в России: несостоявшаяся вторая эпидемиологическая революция // Демографическое обозрение. Т.1, № 4: 5-40.

Вишневский А.Г., В.М. Школьников (1997). Смертность в России: главные группы риска и приоритеты действия. М.: Научные доклады Московского Центра Карнеги. Вып. 19.

Вишневский А.Г., Е.М. Андреев, С.А. Тимонин (2015). Влияние болезней системы кровообращения на демографическое развитие России // Аналитический вестник Совета Федерации Федерального Собрания РФ: 61-78.

Воспроизводство населения СССР (1983) / Под ред. А.Г. Вишневского, А.Г. Волкова. М.: Статистика.

Данилова И.А. (2015). Проблемы качества российской статистики причин смерти в старческом возрасте // Успехи геронтологии. Т.28. №3: 409-414.

Какорина Е.П. Старость не причина (2013) // Медицинский вестник. 8 (621). URL: http://www.medvestnik.ru/articles/starost_ne_prichina (дата обращения: 16.01.2016).

Милле Ф., В.М. Школьников, В. Эртриш, Ж. Валлен (1996). Современные тенденции смертности по причинам смерти в России: 1965-1994. Париж: INED. Двуязычное издание [Meslé F., V.M. Shkolnikov, V.Hertrich, J. Vallin. (1996). Tendances récentes de la mortalité par cause en Russie 1965-1994. Paris: INED].

МКБ-10 (1995). Международная статистическая классификация болезней и проблем, связанных со здоровьем: МКБ-10. В 3-х томах. Т.1. Ч.1. М.: Медицина.

РосБРиС (2015). Российская база данных по рождаемости и смертности Центра демографических исследований Российской Экономической Школы. URL: http://www.demogr.nes.ru/index.php/ru/demogr_indicat/data (дата обращения: 20.09.2015).

Danilova I., V.M. Shkolnikov, D.A. Jdanov, F. Meslé, J. Vallin (2016). Identifying potential differences in cause-of-death coding practices across Russian regions // Population Health Metrics. 14 (8). URL: http://pophealthmetrics.biomedcentral.com/articles/10.1186/s12963016- 0078-0 (дата обращения: 22.03.2016).

Grigoriev P., F. Meslé, V. M. Shkolnikov, E.Andreev, A. Fihel, M. Pechholdova, J. Vallin (2014). The recent mortality decline in Russia: beginning of the cardiovascular revolution? // Population and Development Review. 40(1): 107-129. 
HLD (2015). Human Life-Table Database. Max Planck Institute for Demographic Research (MPIDR), Rostock, Germany; Department of Demography, University of California, Berkeley, USA; Institut national d'études démographiques (INED), Paris, France. URL: http://www.lifetable.de/ (дата обращения: 20.09.2015).

HMD (2015). The Human Mortality Database. Department of Demography, University of California, Berkeley; Max Planck Institute for Demographic Research, Rostock, Germany. URL: http://mortality.org (дата обращения: 20.09.2015).

Leon D., V.M. Shkolnikov, M. McKee, N. Kiryanov, E. Andreev (2010). Alcohol increases circulatory disease mortality in Russia: acute and chronic effects or misattribution of cause? // International Journal of Epidemiology. 39:1279-1290

Meslé F., J. Vallin (2006). The health transition: trends and prospects // G. Caselli, J. Vallin, G. Wunsch, eds. Demography: analysis and synthesis. A treatise in population studies. New York: Academic Press. Vol. II: 247-259.

Meslé F., J. Vallin (2011). Historical trends in mortality // R. G. Rogers, E. M. Crimmins, eds. International Handbook of Adult Mortality. Dordrecht: Springer: 9-47.

Omran A. R. (1971). The epidemiologic transition: a theory of the epidemiology of population change // The Milbank Memorial Fund Quarterly. 49 (4): 509-538.

Terris M. (1976). The Epidemiologic revolution, national health insurance and the role of health departments // American Journal of Public Health. 12 (66).

WHO MD (2015). World Health Organization Mortality Database. WHO. URL: http://www.who.int/healthinfo/mortality_data/en/ (дата обращения: 20.09.2015).

ZaridzeD., Maximovitch D., Lazarev A., Igitov A., Boroda A., Boreham J., Boyle P., PetoR., Boffetta P. (2009). Alcohol poisoning is a main determinant of recent mortality trends in Russia: evidence from a detailed analysis of mortality statistics and autopsies // International Journal of Epidemiology. 38: 143-53. 


\title{
MORTALITY FROM CARDIOVASCULAR DISEASES AND LIFE EXPECTANCY IN RUSSIA *
}

\author{
ANATOLY VISHNEVSKY1, ** , EVGENY ANDREEV², SERGEY TIMONIN ${ }^{1}$
}

\begin{abstract}
High premature mortality from cardiovascular diseases (CVD) and its long-term adverse trends are one of the main reasons for Russia's lagging behind the developed countries in life expectancy, especially the female population. Despite the mortality decline since 2003, CVD mortality rates at particular ages (30-74 years for men and 30-49 for women) are still higher than they were in 1970.
\end{abstract}

Analysis of long-term changes in life expectancy in Russia shows a negative contribution of changes in CVD mortality for men (-1.0 years in 1972-2010) and a small positive contribution for women (0.7 years in 19722010).

The mortality structure within the class of cardiovascular diseases in Russia is significantly different from that observed in those countries with the lowest level of CVD mortality. Ischemic heart disease constitutes more than half of all deaths, and this share, in contrast to Western countries, tends to be on the rise. Second place belongs to deaths from cerebrovascular diseases, the share of which is declining, but remains significantly higher than in Western countries. The share of deaths from all other cardiovascular diseases accounts for about 50\% of deaths in Western countries, while in Russia it accounts for only about 15\%, but is characterized by a very low age at death.

Regional patterns of CVD mortality in Russia are discussed, as well as the quality of statistics on causes of death and the changes in coding practices in the Russian Federation.

Key words: mortality, life expectancy, cardiovascular diseases, ischemic heart disease, cerebrovascular diseases, age-specific mortality pattern, average age of death, excess mortality.

\section{REFERENCES}

Biryukov V.A. (1979). Serdechno-sosudistyye zabolevaniya i prodolzhitel'nost' zhizni [Cardiovascular disease and life expectancy] // E.M. Andreev, A.G. Vishnevsky, eds. Prodolzhitel'nost' zhizni: analiz i modelirovaniye [Life expectancy: analysis and modeling]. Sbornik statey [Collection of articles]. Moscow: Statistika.

Danilova I., V.M. Shkolnikov, D.A. Jdanov, F. Meslé, J. Vallin (2016). Identifying potential differences in cause-of-death coding practices across Russian regions // Population Health Metrics. 14:8. URL: http://pophealthmetrics.biomedcentral.com/articles/10.1186/s12963016-0078-0 (accessed: 22.03.2016).

Danilova I.A. (2015). Problemy kachestva rossiyskoy statistiki prichin smerti v starcheskom vozraste [The issue of quality of Russian cause-specific mortality statistics at old ages] // Uspekhi gerontologii [Adv. Geront.]. V.28. № 3: 409-414.

Grigoriev P., F. Meslé, V.M. Shkolnikov, E. Andreev, A. Fihel, M. Pechholdova, J. Vallin (2014). The Recent mortality decline in Russia: beginning of the cardiovascular revolution? // Population and Development review. 40(1): 107-129.

\footnotetext{
${ }^{1}$ National Research University Higher School of Economics (Russia); 2 New Economic School (Russia).

* THE RESUlts OF THE PROJECT "DEMOGRAPHIC DEVELOPMENT IN RUSSIA IN 2005-2015 IN THE CONTEXT OF LONG-TERM TRENDS", CARRIED OUT WITHIN THE FRAMEWORK OF THE BASIC RESEARCH PROGRAM AT THE NATIONAL RESEARCH UNIVERSITY HigHER SCHOOL OF ECONOMICS (HSE) IN 2016, ARE PRESENTED IN THIS WORK. PARTICIPATION OF S. TIMONIN IS SUPPORTED BY RFBR (RESEARCH PROJECT 16-36-OO374).

** CORRESPONDENCE: avishnevsky@hse.ru

DATE RECEIVED: NOVEMBER 2015.
} 
HLD (2015). Human Life-Table Database. Max Planck Institute for Demographic Research (MPIDR), Rostock, Germany; Department of Demography, University of California, Berkeley, USA; Institut national d'études démographiques (INED), Paris, France. URL: http://www.lifetable.de/ (дата обращения: 20.09.2015).

HMD (2015). The Human Mortality Database. Department of Demography, University of California, Berkeley; Max Planck Institute for Demographic Research, Rostock, Germany. URL: http://mortality.org (дата обращения: 20.09.2015).

Kakorina Y.P. Starost' ne prichina [Senility is not a cause of death] (2013) // Meditsinskiy vestnik [Medical Annals]. 8 (621). URL:

http://www.medvestnik.ru/articles/starost_ne_prichina (accessed: 16.01.2016).

Leon D., V.M. Shkolnikov, M. McKee, N. Kiryanov, E. Andreev (2010). Alcohol increases circulatory disease mortality in Russia: acute and chronic effects or misattribution of cause? // International Journal of Epidemiology. 39:1279-1290

Meslé F., J. Vallin (2006). The health transition: Trends and prospects // G. Caselli, J. Vallin, G. Wunsch, eds. Demography: analysis and synthesis. A treatise in population studies. New York: Academic Press. Vol. II: 247-259.

Meslé F., J. Vallin (2011). Historical trends in mortality // R. G. Rogers, E. M. Crimmins, eds. International Handbook of Adult Mortality. Dordrecht: Springer: 9-47.

Meslé F., V.M. Shkolnikov, V. Hertrich, J. Vallin. (1996). Sovremennyye tendentsii smertnosti po prichinam smerti v Rossii: 1965-1994 [Modern trends in causes of death in Russia: 19651994]. Paris: INED. [Meslé F., V.M. Shkolnikov, V.Hertrich, J. Vallin. (1996). Tendances récentes de la mortalité par cause en Russie 1965-1994. Paris: INED].

MKB-10 [ICD-10] (1995). Mezhdunarodnaya statisticheskaya klassifikatsiya bolezney i problem, svyazannykh so zdorov'yem: MKB-10 [International statistical classification of diseases and related health problems. 10th Revision]. V 3-kh tomakh [Three volumes]. Tom 1 [Volume 1]. Chast' 1 [Part 1]. Moscow: Meditsina.

Omran A. R. (1971). The epidemiologic transition: a theory of the epidemiology of population change // The Milbank Memorial Fund Quarterly. 49 (4): 509-538.

RosBRiS (2015). Rossiyskaya baza dannykh po rozhdayemosti i smertnosti Tsentra demograficheskikh issledovaniy Rossiyskoy Ekonomicheskoy Shkoly [Russian Fertility and Mortality Database. Center for Demographic Research, Moscow (Russia)]. URL: http://www.demogr.nes.ru/index.php/ru/demogr_indicat/data (accessed: 20.09.2015).

Terris M. (1976). The epidemiologic revolution, national health insurance and the role of health departments // American Journal of Public Health. 12 (66).

Vishnevsky A.G. (2014). Smertnost' v Rossii: nesostoyavshayasya vtoraya epidemiologicheskaya revolyutsiya [Mortality in Russia: the second epidemiologic revolution that never was] // Demograficheskoye obozreniye [Demographic Review]. Vol.1, №4: 5- 40 .

Vishnevsky A.G., E.M. Andreev, S.A. Timonin (2015). Vliyaniye bolezney sistemy krovoobrashcheniya na demograficheskoye razvitiye Rossii [Impact of circulatory system diseases on the demographic development of Russia] // Analiticheskiy vestnik Soveta Federatsii Federal'nogo Sobraniya RF [Analytical Annals of the Federation Council of the Federal Assembly of the Russian Federation]: 61-78.

Vishnevsky A.G. (1986). Chelovecheskiy faktor v demograficheskom izmerenii [Human factor in the demographic dimension] // Kommunist [Communist]. 17: 69-80. 
Vishnevsky A.G., V.M. Shkolnikov. (1997). Smertnost' v Rossii: glavnyye gruppy riska i prioritety deystviya [Mortality in Russia: main risk groups and priorities for acting]. M.: Nauchnyye doklady Moskovskogo Tsentra Karnegi [Scientific reports of the Carnegie Moscow Center]. Issue 19.

Vosproizvodstvo naseleniya SSSR [Population reproduction in the USSR] (1983) / A.G. Vishnevsky, A.G. Volkov, eds. Moscow: Statistika.

WHO MD (2015). World Health Organization Mortality Database. WHO. URL: http://www.who.int/healthinfo/mortality_data/en/ (accessed: 20.09.2015).

ZaridzeD., Maximovitch D., Lazarev A., Igitov A., Boroda A., Boreham J., Boyle P., PetoR., Boffetta P. (2009). Alcohol poisoning is a main determinant of recent mortality trends in Russia: evidence from a detailed analysis of mortality statistics and autopsies // International Journal of Epidemiology. 38: 143-53. 